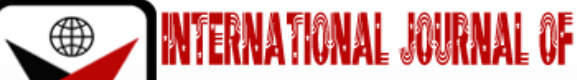 \\ TNOWATVE REFARCH \& DEVEDOPWENT
}

ISSN 2278-0211 (Online)

\section{Assessment of the Properties of Soil in Flooded and Upland Forest Areas in Yola North Local Government Area of Adamawa State, Nigeria}

\author{
Garandi Ijudigal Danjuma \\ Lecturer, Department of Geography, \\ Adamawa State University, Mubi, Adamawa State, Nigeria
}

\begin{abstract}
:
Floods are among the most devastating natural disasters in the world, claiming more lives and causing more property damages than any other natural phenomena. In recent times, the incidence of flooding across Nigeria has left both the government and the governed devastated. It is no longer news that flooding and its attendant consequences are injurious to man while the spatial dimensions are often not mapped. This study, therefore, Analysis of Physical and Chemical Properties of Soils in flooded and Upland Forest areas of Yola-North. Flood analysis for low, medium and high flow regimes showed that physical and chemical properties of soils are being affected. Longitudinal and cross section profiles depict the trend in which sediment loads are transported by flood and presence of boulders along the Benue channel. Sustainable measures such as review of Federal Environmental Protection Agency (FEPA) 1999 flood combat measures, dredging of the Benue and relocation of people living near river banks were suggested for the management of flooding in Adamawa State
\end{abstract}

Keywords: Flooding, Soil property

\section{Introduction}

Floods are among the most devastating natural disasters and cost many lives every year (Azuhan, 2015). Flooding seriously affects people's lives and property (Zhang et al., 2013). In a time period of 6 years (1989-1994), 80\% of federal declared disasters in the US were related to flooding; flood themselves around the world average four billion dollars annually in property damage alone (Njoku and Okoro, 2015). The frequency with which they occur is on the increase in many regions of the world (Drogue et al., 2014). Thus, considering their general makeup, settlements are of major concern when discussing flood hazard. Going by number and economic losses, flood disasters account for about a third of all natural disasters (Nwiloet al., 2012). Nigeria is no exception to countries that experienced flooding in recent time. Many communities have suffered losses due to flood problem. Nigeria like many other coastal countries of the world is blessed with a plethora of drainage systems of varied river morphometry (Daffi, 2013).

The dramatic river flooding in Adamawa State that destroyed farmlands and claimed lives and property has affected various parts of the region. Sequel to the topography and sediment type of the study area, possibility of spread exists. Some of the flood prone areas include Yola North and South, Numan Council areas, Loko, Dasin, Fufore areas and Demsa. Galtima and Bashir (2002) recorded a very severe destruction in Fufore council to the extent that as many as 13 villages were submerged and hundreds of hectares of farmland washed away.

The need and means to protect the environment are of great concern to man. Flood Management is currently a key focus of many national and international research programmes with flooding from rivers, estuaries and the sea posing a serious threat to millions of people around the world during a period of extreme climate variability, [Flood Risk Management Research Consortium (FRMRC), 2010]. Flood occurrences in Adamawa State floodplain are threats to lives and properties and the frequency is increasing dramatically.

Floods in Adamawa state usually leave over 2,000 people displaced many of them with no access to clean drinking water, leading to cholera outbreaks. According to the Nigeria Emergency Management Agency (NEMA), five districts, namely, Fufore, Demsa, Yola North, Yola South and Numan were flooded in August and early September, 2010 when River Lagdo burst its banks. Demsa and Fufore districts, along with nearby Maiha, were hit with cholera outbreak which left 70 people dead out of over 300 infected (Daily Trust, 2010).

Flooding generally affect the soil through its physical and chemical properties. Flood has been identified as a serious environmental problem with a multiplicity of social and economic consequences. Flooding uses disastrous form of land degradation whose effect is multi-dimensional. According to Ubuoh et al., (2016), flood affect the physical properties of soil through lowering the nutrient level often associated with subsoil and hence provide less protection to the soil. Flooding leads to poorer structure and lower organic matter. Sediment can be deposited on down slope properties and can 
contribute to road impedance damage also leading to loss in revenue finances and impediment to urbanization (Ubuoh et al., 2016).

According to Njoku et al. (2011), when a soil is flooded and not controlled, its oxygen supply decreases to zero in less than a day. The rate of atmospheric oxygen diffusion is 10,000 times slower through water layers or water filled pores than through air- or air-filled pores. Aerobic micro-organisms quickly consume the remaining oxygen and become dormant or die. Anaerobes or facultative anaerobes multiply rapidly and take over the organic matter decomposition process, using instead of oxygen, oxidized soil components as electron acceptors. These products are reduced in the following thermodynamic sequence: nitrates, manganic compounds, ferric compounds, intermediate products of organic matter decomposition, sulphates, and sulphites.

The result is to change the soil from the oxidized to the reduced state. The oxidation - reduction potential (Eh values corrected to $\mathrm{pH} 7$ ) is a useful parameter for measuring the intensity of soil reduction and for identifying the predominant reactions taking place. Njoku et al. (2011), stated that, the chemical status of a flooded soil differs widely from that of upland land. The former is characterized by a deficiency of oxygen and excess of carbon dioxide. The effect of flooding is to initiate anaerobic decomposition of organic matter and increase in solubility of phosphates and silica. It also results in the presence of sulphides and a large amount of reduced iron and magnesium, the absence of nitrate and an increase in electrical conductivity.

In the humid tropics the rate of decomposition of soil minerals may be increased by 20 to 30 times. The soil in a submerged paddy field consists of a thin surface oxidizing layer below which is a reducing layer. Much of the organic nitrogen in the reducing layer is released as ammonia, which the paddy plant can fully utilize with the simultaneously reduced phosphorus.

Njoku et al. (2011) concluded that flooded soils are low in pH, organic matter, and exchangeable cations. The Fe oxide in these soils was assumed to have been in suspension of floodwater attached to clay particles, and subsequently deposited. They are mainly found in concretions and as coatings.

\subsection{Objectives of the Study}

- To determine the effect of flooding on physical and chemical properties of soils.

- To determine the difference in soil nutrient status of the flood plains in relation to that of the upland areas adjacent to the flood plains.

\subsection{Hypothesis}

- $\mathrm{H}_{01}$ : There are no significant differences between the physical and chemical properties of soil in flooded and upland forest areas of Yola North and South

- $\mathrm{H}_{02}$ : The nutrient concentration of soil in the forest area is not significantly correlated with the nutrient concentration of soils of the floodplains.

- $\mathrm{H}_{03}$ : The properties of soil in the forest areas are not significantly related to the properties of soil in floodplains.

\section{Materials and Methods}

Adamawa State is located at the North Eastern part of Nigeria. It lies between latitude $7^{\circ}$ and $11^{\circ} \mathrm{N}$ of the equator and between longitude $11^{\circ}$ and $14^{\circ} \mathrm{E}$ of the Greenwich meridian E in the Upper Benue catchment. It shares boundary with Taraba State in the South and West, Gombe State in its Northwest and Borno State to the North. Adamawa State has an international boundary with the Cameroon Republic along its eastern boarder. The State covers a land area of about $38,741 \mathrm{~km}^{2}$. It is divided into 21 local Government Areas (Figure 1) is the map of Nigeria showing the study area in red (Adebayo, 1999). It has a population of 3,168,101 (National Bureau for Statistics, 2007). 


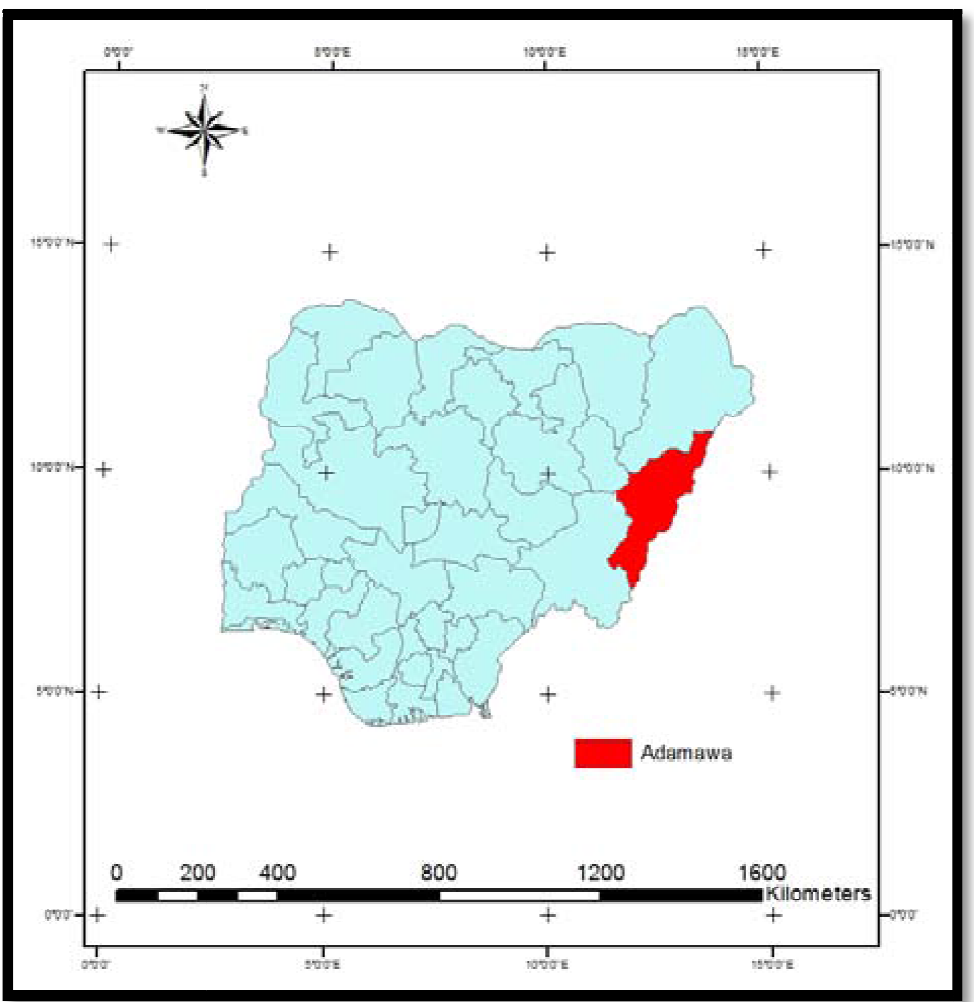

Figure 1: Map of Nigeria Showing Adamawa State in Red Analogue Map, Scanned and Modified By Authors) Source: Adebayo (1999)

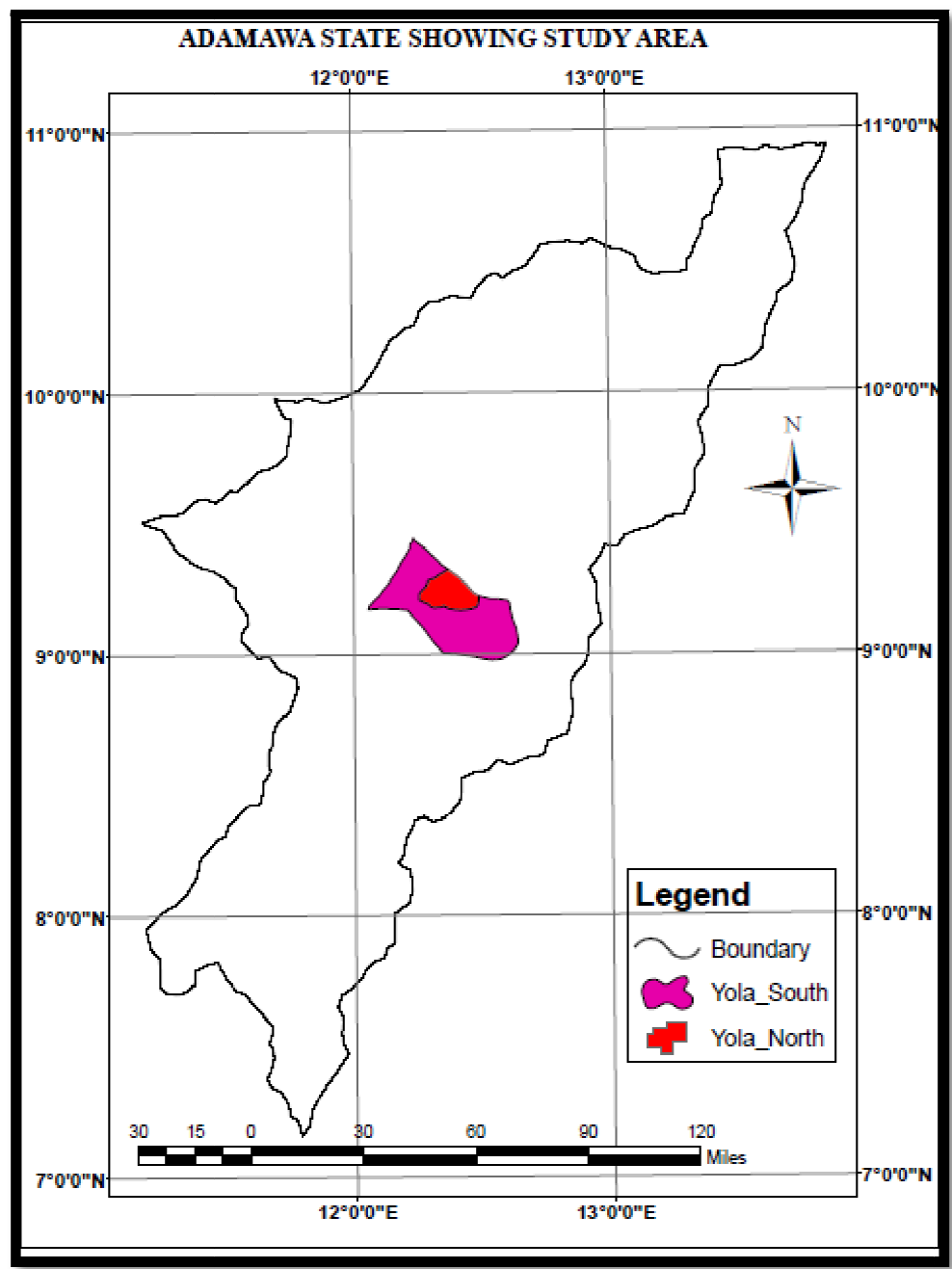

Figure 2: Map of Adamawa State Showing the Study Sites. Source: Adebayo (1999) 


\subsection{Adamawa Flood Plains}

Adamawa flood plains span two Nigeria agroecological zones. Dry sub-humid Chibok-Biu-Mubi-Song high plain and Dry sub-humid Azare-Gombe-Yola plain (Nwilo et al., 2012).

\subsection{Soils of the Zone}

The soils of the zone are varied and are greatly influenced by parent materials and topography. In general, the soils of the area are largely suitable for crop production but the major soil management problems that were encountered are coarse texture, low nutrient status and low retention of moisture on the sandy upland soils; and poor drainage, fine texture or vatic properties and flooding hazards in the case of the very fertile soils of the extensive flood plains and clay fats (Nwilo et al., 2012)

\subsection{Site Selection}

A reconnaissance survey of the flood plains was carried out since a lot of the lands have been converted to either agricultural farmlands or settlement areas, two sites were therefore be purposively sampled in study area for data collection Runde-Baru and Jambutu, in Yola North LGA having both the flooded and upland areas.

\subsection{Data Collection}

\subsubsection{Collection of Soil Samples}

Sample soils were randomly collected from five selected points in each of the flooded area (location A) and $200 \mathrm{~m}$ adjacent from the site i.e., at the upland area (location B). At each point one sample was taken at three depths. $0-30 \mathrm{~cm}, 30$ $60 \mathrm{~cm}$ and $60-90 \mathrm{~cm}$ using hand Auger. All of the samples were labeled appropriately in cellophane bags for onward determination of soil physical and chemical properties in the laboratory.

Similarly, soil samples were also collected from upland areas of each location adjacent to the study sites for purposes of comparison.

\subsubsection{Determination of Physical and Chemical Properties in Soil Samples}

The determination of physical and chemical properties in soil samples was carried out in the soil science laboratory of ModibboAdama University of Technology Yola. The samples were first air-dried and later ground using pestle and mortar. They were then sieved to pass through a $<2 \mathrm{~mm}$ sieve.

\subsubsection{Laboratory Analysis}

The soil samples collected were air dried and crushed using a mortar and pestle to pass through a $2 \mathrm{~mm}$ sieve. The samples were well packaged in polythene bags and labeled accordingly. The samples were characterized for their physical and chemical properties following standard laboratory procedures.

\subsection{Soil Physical Analysis}

\subsubsection{Mechanical Analysis}

Mechanical analyses of soils were determined using a Soil Hydrometer after dispersing the soil water solution with Calgon (Sodium metahexaphosphate solution). The sand, silt and clay fractions were computed from hydrometer and thermometer readings.

\subsubsection{Soil Bulk Density}

Soil bulk density was determined from soil cores taken from the field. The oven dry weight of the sample was determined in laboratory and the bulk density was determined by dividing the weight of soil by volume of core sampler.

\subsubsection{Porosity}

Total porosity was calculated using the formular:

$\begin{array}{lll}\mathrm{F} & =1-\mathrm{Db} / \mathrm{Dp} \times 100 \\ \text { Where } \mathrm{F} & = & \text { Total porosity } \\ \mathrm{Db} & = & \text { Bulk density } \\ \mathrm{Dp} & = & \text { particle density }\end{array}$

\subsubsection{Soil Chemical Analysis}

\section{(i) Soil $\mathrm{pH}$}

Soil $\mathrm{pH}$ was determined in 1: 2 (Soil: Water) suspension using pH meter, value was adjusted at $20^{\circ} \mathrm{C}$.

(ii) Electrical Conductivity EC

The soil Electrical conductivity was determined in 1: 2 (soil: Water) suspension using electrical conductivity meter.

(iii) Organic Carbon Determination (OC \%)

Soil organic carbon was determined using the Wet Oxidation method of Walkley and Black, using Potassium Dichromate and concentrated Sulphuric Acid. A blank experiment always runs without soil in order to know the un-used potassium dichromate in soil sample experiments. 


\section{(iv) Available Phosphorus (Av P)}

Available phosphorus in soil was determined by extracting the soil with dilute HO (Bray-1) where pH of soil was neutral or acidic. Sodium - bicarbonate (Olson's method) extraction was used where soil pH was alkaline. The extract was used for determination of available P calorimetrically developing blue color.

(v) Total Nitrogen (TN) in Soils

Total nitrogen content of the soil was determined by the Kjeldahls wet digestion method.

Exchangeable Cations in Soils

Exchangeable cations Calcium (Ca), Magnesium (Mg), Potassium (K) and Sodium (Na) were determined from the extract of soil treated with neutral normal ammonium acetate $(\mathrm{pH}$ 7.0). Calcium and Magnesium were determined by titration, whereas $\mathrm{K}$ and Na were determined using a flame photometer.

(vii) Total Exchangeable Acidity (TEA)

Exchangeable acidity $(\mathrm{H}+\mathrm{Al})$ of soil samples were determined by extraction from the soil samples with $1 \mathrm{~N}, \mathrm{KCl}$ and the extract was titrated with $1 \mathrm{~N}$ Sodium hydroxide. The exchangeable acidity was calculated from titre value.

(viii) Total Exchangeable Bases (TEB)

Total Exchangeable bases of soil was determined by summing up the values of all the exchangeable cations (Ca, $\mathrm{Mg}, \mathrm{K}$ and $\mathrm{Na}$ ).

(ix) Effective Cation Exchange Capacity (ECEC)

Effective Cation Exchange Capacity of soil was determined by summing up the values of all the exchangeable cations ( $\mathrm{Ca}, \mathrm{Mg}, \mathrm{K}, \mathrm{Na}, \mathrm{Al}$ and $\mathrm{H}$ )

(x) Base Saturation BS (\%)

The percentage base saturation was calculated by dividing the value of Effective Cation Exchange Capacity by the total value of exchangeable bases (Ca, Mg, K and Na plus exchangeable acidity) and multiplied by 100 .

(xi) Sodium Absorption Ratio (SAR)

SAR was calculated using the formular:

$$
\mathrm{SAR}=\frac{\frac{\mathrm{Na}}{\sqrt{(\mathrm{Ca}+\mathrm{Mg})}}}{2}
$$

Where: $\mathrm{Na}=$ Sodium, $\mathrm{Ca}=$ Calcium and $\mathrm{Mg}=$ Magnissium,

\subsection{Sampling Design}

The concentrations of physical and chemical properties in the soils of the flood plains were subjected to a TwoWay Analysis of Variance (MANOVA) in Randomized Complete Block Design (RCBD); with model: $Y_{i j}=\mu+b_{i}+f_{j}+s k+(f x$ $s) j k+e_{i j k}$

Where:

$\mu=$ the overall mean

$\mathrm{bi}^{\mathrm{i}}=$ effect of the $\mathrm{i}^{\text {th }}$ block

$\mathrm{fj}=$ effect of the $\mathrm{j}^{\text {th }}$ physical and chemical properties

sk $=$ effect of the $\mathrm{k}^{\text {th }}$ soil

$\mathrm{f} \times \mathrm{s}=$ interaction effect of the $\mathrm{j}^{\text {th }}$ and $\mathrm{k}^{\text {th }}$ term

$\mathrm{e}_{\mathrm{ij}}=$ random error

The floodplains constitute the blocks while the physical and chemical properties of soil parameters are the treatments respectively. Mean separation were done using Duncan Multiple Range Test.

\section{Results and Discussion}

\subsection{Physical Contents of Flooded and Upland Soils in Yola North}

The results of the physical contents of flooded and upland soilsin Yola-North are presented in Table 1.

\subsection{Sand Contents of the Flooded and Upland Soils in Yola North LGA}

In the flooded area of Yola-North LGA, the highest and the least sand contents of $47.00 \%$ and $30.67 \%$ were recorded at the depths of $30-60 \mathrm{~cm}$ and $0-30 \mathrm{~cm}$ respectively. Location wise Jambutu (L1) and Runde-Baru (L2) and had the least and the highest sand contents of $37.00 \%$ and $39.00 \%$ respectively (Table 1). Also, in the upland area of the same LGA, the highest and the least sand contents of $67.00 \%$ and $50.50 \%$ were recorded at depths $0-30 \mathrm{~cm}$ and $30-60 \mathrm{~cm}$ respectively and location wise, Jambutu (L1) had the highest sand contents of $70.00 \%$, while the least sand contents of $58.67 \%$ was recorded at Runde-Baru (L2). The Analysis of variance of sand contents of flooded and upland areas showed significant difference at $\mathrm{p}<0.05$.

\subsection{Silt Contents of the Flooded and Upland Soils in Yola North LGA}

The results of silt contents for the flooded and upland areas in the Yola-North are presented in the Table 1. In the flooded area of Yola-North LGA, the highest and the least silt contents of $19.50 \%$ and $15.00 \%$ were recorded at the depths of $0-30 \mathrm{~cm}$ and $60-90 \mathrm{~cm}$ respectively. Location wise, Jambutu (L1) and Runde-Baru (L2) had the highest and the least silt contents of $16.67 \%$ and $15.00 \%$ respectively. Also, in the upland area of the same LGA, the highest and the least silt contents of $13.00 \%$ and $7.00 \%$ were recorded at depths $60-90$ and $0-30 \mathrm{~cm}$ respectively and location wise, Runde-Baru (L2) had the highest Silt contents of $12.00 \%$, while the least silt contents of $11.33 \%$ was recorded at Jambutu (L1). The analysis of variance of the silt contents of the flooded and upland area showed a significant difference at $\mathrm{p}<0.05$. 


\subsection{Clay Contents of the Flooded and Upland Soils in Yola North LGA}

In the flooded area of Yola-North LGA, the highest and the least clay contents of $38.50 \%$ and $35.67 \%$ were recorded at the depths of $60-90 \mathrm{~cm}$ and $0-30 \mathrm{~cm}$ respectively. Across the location, Jambutu (L1) and Runde-Baru (L2) had the highest and the least clay contents of $46.00 \%$ and $35.67 \%$ respectively (Table 1). Also, in the upland area of the same LGA, the highest and the least clay contents of $32.50 \%$ and $26.00 \%$ were recorded at depths $30-60 \mathrm{~cm}$ and $0-30$ $\mathrm{cm}$ respectively and location wise, Runde-Baru (L2) had the highest clay contents of $29.33 \%$, while the least clay contents of $19.00 \%$ was recorded at Jambutu (L1). Analysis of variance of clay contents of flooded and upland areas showed significant difference at $\mathrm{p}<0.05$.

\subsection{Texture Classes of the Flooded and Upland Soils in Yola North LGA}

The results of the texture classes for the flooded and upland area in the Yola-North LGA showed that in all locations and across depths, the sand texture classes were dominated by sandy clay, clay and loam respectively.

\subsection{Bulk Density Contents of the Flooded and Upland Soils in Yola North LGA}

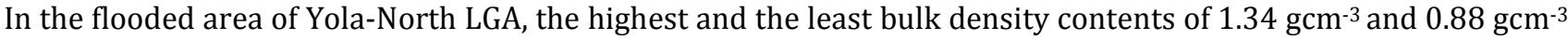
were recorded at the depths of $30-60 \mathrm{~cm}$ and $0-30 \mathrm{~cm}$ respectively. Location wise, Runde-Baru (L2) and Jambutu (L1) had the highest and the least bulk density contents of $1.29 \mathrm{gcm}^{-3}$ and $1.28 \mathrm{gcm}^{-3}$ respectively (Table 1). Also, in the upland area of the same LGA, the highest and the least bulk density contents of $1.49 \mathrm{gcm}^{-3}$ and $1.35 \mathrm{gcm}^{-3}$ were recorded at depths $0-30 \mathrm{~cm}$ and $30-60 \mathrm{~cm}$ respectively, while, Jambutu (L1) had the highest bulk density contents of $1.53 \mathrm{gcm}^{-3}$ and the least bulk density content of $1.39 \mathrm{gcm}^{-3}$ was recorded at Runde-Baru (L2). Analysis of variance of bulk density contents of flooded and upland areas showed no significant difference at $\mathrm{p}>0.05$.

\subsection{Porosity of the Flooded and Upland Soils in Yola North LGA}

In the flooded area of Yola-North LGA, the highest and the least porosity of $53.22 \%$ and $49.59 \%$ were recorded at the depths of $60-90 \mathrm{~cm}$ and $0-30 \mathrm{~cm}$ respectively. Location wise, Jambutu (L1) and Runde-Baru (L2) had the highest and the least porosity of $51.67 \%$ and $49.36 \%$ respectively (Table 1 ).

\begin{tabular}{|c|c|c|c|c|c|c|}
\hline Sample & Sand (\%) & Silt (\%) & Clay (\%) & $\begin{array}{l}\text { Textural } \\
\text { Classes }\end{array}$ & $\begin{array}{c}\text { Bulk } \\
\text { Density } \\
\left(\mathrm{gcm}^{-3}\right)\end{array}$ & $\begin{array}{c}\text { Porosity } \\
\text { (\%) }\end{array}$ \\
\hline \multicolumn{7}{|l|}{$\begin{array}{l}\text { Flood Area } \\
\text { Depths }\end{array}$} \\
\hline $0-30$ & $30.67 c$ & $19.50 \mathrm{a}$ & $35.67 \mathrm{~b}$ & Clay & $0.88 \mathrm{~b}$ & $53.22 \mathrm{a}$ \\
\hline $30-60$ & $42.00 \mathrm{c}$ & $16.00 \mathrm{~b}$ & $38.50 a$ & Sandy clay & $1.33 \mathrm{a}$ & $50.34 b$ \\
\hline $60-90$ & $47.00 \mathrm{~b}$ & $15.00 \mathrm{a}$ & $38.00 \mathrm{a}$ & Clay & $1.34 \mathrm{a}$ & $49.59 b$ \\
\hline S.E+ & 6.112 & 1.453 & 3.885 & & 0.153 & 5.379 \\
\hline CV\% & 24.779 & 19.868 & 20.155 & & 22.297 & 21.184 \\
\hline \multicolumn{7}{|l|}{ Location } \\
\hline L1 & $37.00 \mathrm{~b}$ & $16.67 \mathrm{a}$ & $46.00 \mathrm{a}$ & Sandy, Loam & $1.28 \mathrm{a}$ & $51.67 a$ \\
\hline $\mathrm{L} 2$ & $39.00 \mathrm{~b}$ & $15.00 \mathrm{a}$ & $35.67 a$ & Clay & $1.29 \mathrm{a}$ & $49.36 a$ \\
\hline S.E+ & 10.833 & 2.333 & 8.333 & & 0.057 & 2.152 \\
\hline CV\% & 32.029 & 23.022 & 31.288 & & 5.995 & 6.145 \\
\hline \multicolumn{7}{|c|}{$\begin{array}{l}\text { Upland Area } \\
\text { Depths }\end{array}$} \\
\hline $0-30$ & $67.00 \mathrm{a}$ & $07.00 \mathrm{~b}$ & $26.00 \mathrm{c}$ & Sandy, clay & $1.49 \mathrm{a}$ & $33.45 \mathrm{c}$ \\
\hline $30-60$ & $50.50 a$ & $13.00 \mathrm{a}$ & $32.50 \mathrm{ab}$ & Sandy clay & $1.35 \mathrm{a}$ & $39.13 a$ \\
\hline $60-90$ & $54.50 \mathrm{~b}$ & $09.00 \mathrm{a}$ & $31.00 \mathrm{~b}$ & Sandy clay & $1.41 \mathrm{a}$ & $36.90 \mathrm{~b}$ \\
\hline S.E+ & 7.217 & 3.609 & 3.609 & & 0.048 & 1.988 \\
\hline CV\% & 22.936 & 47.481 & 19.335 & & 5.859 & 7.341 \\
\hline \multicolumn{7}{|l|}{ Location } \\
\hline L1 & $70.00 \mathrm{a}$ & $11.33 b$ & $19.00 \mathrm{~b}$ & Clay & $1.53 \mathrm{a}$ & $37.12 \mathrm{a}$ \\
\hline $\mathrm{L} 2$ & $58.67 a$ & $12.00 \mathrm{~b}$ & $29.33 b$ & Loamy Sand & $1.39 \mathrm{a}$ & $38.36 a$ \\
\hline S.E+ & 15.500 & 1.833 & 13.333 & & 0.122 & 4.773 \\
\hline CV\% & 40.221 & 19.692 & 58.318 & & 12.217 & 14.395 \\
\hline P-value & 0.041 & 0.032 & 0.025 & & 0.611 & 0.015 \\
\hline
\end{tabular}

Table 1: Physical Properties of the Flooded and Upland Area in Yola-North LGA

L1 \&L2 at Yola-North Are Jambutuand Runde-BaruRespectively, Source: Field Survey (2020)

Also, in the upland area of the same LGA, the highest and the least porosity of $39.13 \%$ and $33.45 \%$ were recorded at depths $30-60 \mathrm{~cm}$ and $0-30 \mathrm{~cm}$ respectively, and location wise, Runde-Baru (L2) had the highest porosity of $38.36 \%$, while the least porosity content of $37.12 \%$ was recorded at Jambutu (L1). Analysis of variance of Porosity of flooded and upland areas showed significant difference at $\mathrm{p}<0.05$. 


\subsection{Chemical Properties of Flooded and Upland Soils in Yola-North LGA}

The results of the chemical contents of flooded and upland soilsin Yola North LGA are presented Tables 2

\subsection{1. $\mathrm{PH}^{\mathrm{H}}$ of Sampled Soils from Flooded and Upland Areas of Yola North LGA}

The results of $\mathrm{pH}$ level on Table 2, show that in flooded area of Yola-North LGA, the pH values ranged between $6.76-7.09$, with the highest and the least values recorded at $30-60 \mathrm{~cm}$ and $0-30 \mathrm{~cm}$ respectively. Samples from RundeBaru (L2) had the highest $\mathrm{pH}$ value of 6.75 while the least $\mathrm{pH}$ value of 6.57 was recorded in the samples from Jambutu (L1). The $\mathrm{pH}$ values of the upland areas in the same LGA, showed that the highest and the least $\mathrm{pH}$ values of 6.66 and 6.63 were recorded at $0-30 \mathrm{~cm}$ and $30-60 \mathrm{~cm}$ respectively, while the highest and least pH values of 6.65 and 6.64 were recorded in samples from Runde-Baru (L2) and Jambutu (L2) respectively. Analysis of variance of pH contents of flooded and upland area showed no significant difference at $\mathrm{p}>0.05$

\subsubsection{Ec Properties of Sampled Soils from Flooded and Upland Area in Yola North Lga}

The results of EC of the sampled soils from flooded and upland area in Yola-North LGA are presented in Table 2. In the flooded area, the highest and the least EC values of $1.02 \mathrm{ds} / \mathrm{m}$ and $1.11 \mathrm{ds} / \mathrm{m}$ were recorded at $0-30 \mathrm{~cm}$ and $30-60$ $\mathrm{cm}$ respectively. The highest EC value of $1.09 \mathrm{ds} / \mathrm{m}$ was recorded at Jambutu (L1) and the least EC value of $1.07 \mathrm{ds} / \mathrm{m}$ was recorded at Runde-Baru (L2).

In the upland area of the same LGA, the EC values ranged between $1.00-1.040 \mathrm{ds} / \mathrm{m}$, and the highest and the least values were recorded at $0-30 \mathrm{~cm}$ and $30-60 \mathrm{~cm}$ respectively. With regards to location, the EC value of $1.02 \mathrm{ds} / \mathrm{m}$ was recorded at Jambutu (L1), while at Runde-Baru (L2) EC value of $1.01 \mathrm{dS} / \mathrm{m}$ was recorded. Analysis of variance of EC contents of flooded and upland area showed no significant difference at $\mathrm{p}>0.05$.

\subsubsection{OC Properties of Sampled Soils from Flooded and Upland Area in Yola North LGA}

The results of Organic Carbon (OC) for sampled soils from flooded area in Yola-North LGA are presented in Table 3. In the flooded areas, the highest and the least OC values of $6.70 \mathrm{~g} / \mathrm{kg}$ and $6.10 \mathrm{~g} / \mathrm{kg}$ were recorded at $0-30 \mathrm{~cm}$ and $30-$ $60 \mathrm{~cm}$ respectively. The highest and the least OC values of $6.52 \mathrm{~g} / \mathrm{kg}$ and $6.20 \mathrm{~g} / \mathrm{kg}$ were recorded at Runde-Baru (L2) and Jambutu (L1) respectively. In the upland area of the same LGA, the highest and the least OC values of $7.85 \mathrm{~g} / \mathrm{kg}$ and 7.20 $\mathrm{g} / \mathrm{kg}$ were recorded at $30-60 \mathrm{~cm}$ and $0-30 \mathrm{~cm}$ respectively, while across the locations, the highest OC value of $7.63 \mathrm{~g} / \mathrm{kg}$ was recorded at Runde-Baru (L2) and the least OC value of $7.4 \mathrm{~g} / \mathrm{kg}$ was recorded at Jambutu (L1). Analysis of variance of OC contents of flooded and upland area showed significant difference at $\mathrm{p}<0.05$.

\subsubsection{TN Properties of Sampled Soils from Flooded and Upland Area in Yola North LGA}

In flooded area, the highest and the least TN values of $1.80 \mathrm{~g} / \mathrm{kg}$ and $1.40 \mathrm{~g} / \mathrm{kg}$ were recorded at $30-60 \mathrm{~cm}$ and 0 - $30 \mathrm{~cm}$ respectively, while the highest and the least TN values of $1.53 \mathrm{~g} / \mathrm{kg}$ and $1.50 \mathrm{~g} / \mathrm{kg}$ were recorded at Runde-Baru (L2) and Jambutu (L1) respectively. In the upland area of the same LGA, the highest and the least TN values of $1.75 \mathrm{~g} / \mathrm{kg}$ and $1.40 \mathrm{~g} / \mathrm{kg}$ were recorded at $30-60 \mathrm{~cm}$ and $60-90 \mathrm{~cm}$ respectively, while the highest TN value of $1.57 \mathrm{~g} / \mathrm{kg}$ was recorded at Runde-Baru (L2) and the least TN value of $1.53 \mathrm{~g} / \mathrm{kg}$ was recorded at Jambutu (L1). Analysis of variance of TN contents of flooded and upland area showed no significant difference at $\mathrm{p}>0.05$.

\subsubsection{Av-P in Sampled Soils from Flooded and Upland Area in Yola North LGA}

Results of the available phosphorus (Av-P) in the sampled soils of flooded and upland area in Yola-North LGA are presented in Table 3. In the flooded area, the highest and the least Av-P values of $8.22 \mathrm{mgkg}^{-1} \mathrm{and}^{7.01} \mathrm{mgkg}^{-1} \mathrm{were}^{-}$ recorded at $60-90 \mathrm{~cm}$ and $0-30 \mathrm{~cm}$ respectively. With regard to the location, the highest Av- $\mathrm{P}$ value of $8.23 \mathrm{mgkg}-1$ was recorded at Jambutu (L1), while the least Av-P value of $7.68 \mathrm{mgkg}^{-1}$ was recorded at Runde-Baru (L2) respectively. In the upland area of the same LGA, the highest and the least values of $9.90 \mathrm{mgkg}^{-1}$ and $9.43 \mathrm{mgkg}^{-1}$ were recorded at $0-90 \mathrm{~cm}$ and $30-60 \mathrm{~cm}$ respectively, while the highest Av-P value of $9.34 \mathrm{mgkg}^{-1}$ was recorded at Jambutu (L1) and the least Av-P value of $9.30 \mathrm{mgkg}^{-1}$ was recorded at Runde-Baru (L2) respectively. Analysis of variance of Available Phosphorus contents of flooded and upland area showed significant difference at $\mathrm{p}<0.05$.

\subsection{6. $\mathrm{Ca}^{2+}$ In Sampled Soils from Flooded and Upland Area in Yola North LGA}

The results of $\mathrm{Ca}^{2+}$ found in the sampled soil in flooded and upland area in Yola-North LGA, are presented in Table 3. In the flooded area, the highest and the least $\mathrm{Ca}^{2+}$ values of $8.11 \mathrm{Cmolkg}^{-1}$ and $4.33 \mathrm{Cmolkg}^{-1}$ were recorded at $60-90 \mathrm{~cm}$ and $0-30 \mathrm{~cm}$ respectively. In respect to location, Runde-Baru (L2) and Jambutu (L1) recorded the highest and least value of $\mathrm{Ca}^{2+}$ of $7.46 \mathrm{Cmolkg}^{-1}$ and $7.27 \mathrm{Cmolkg}^{-1}$ respectively. In the upland area of the same LGA, the highest and the least values of $\mathrm{Ca}^{2+}$ were $12.07 \mathrm{Cmolkg}^{-1}$ and $11.67 \mathrm{Cmolkg}^{-1}$ recorded at $60-90 \mathrm{~cm}$ and $0-30 \mathrm{~cm}$ respectively. While in Jambutu (L1) recorded highest $\mathrm{Ca}^{2+}$ value of $12.00 \mathrm{Cmolkg}^{-1}$ and Runde-Baru (L2) recorded the least $\mathrm{Ca}^{2+}$ value of 11.65 Cmolkg-1. Analysis of variance of $\mathrm{Ca}^{2+}$ contents of flooded and upland area showed significant difference at $\mathrm{p}<0.05$.

\subsubsection{Mg2+ In Sampled Soils from Flooded and Upland Area in Yola North LGA}

The $\mathrm{Mg}^{2+}$ level found in the soil sampled from flooded and upland area in Yola-North LGA are presented in Table 3. In the upland area, the highest and the least $\mathrm{Mg}^{2+}$ values of $3.95 \mathrm{Cmolkg}^{-1}$ and $2.25 \mathrm{Cmolkg}^{-1}$ were recorded at $0-30 \mathrm{~cm}^{-1}$ and $30-60 \mathrm{~cm}$ respectively. Location wise, the highest $\mathrm{Mg}^{2+}$ value of $3.10 \mathrm{Cmolkg}^{-1}$ was recorded at Jambutu (L1), while the least $\mathrm{Mg}^{2+}$ value of $3.04 \mathrm{Cmolkg}^{-1}$ was recorded at Runde-Baru (L2) respectively. In the upland area of the same LGA, the $\mathrm{Mg}^{2+}$ values across depths were generally less than that of flooded area, with the highest value of 2.06 recorded at $60-$ 
$90 \mathrm{~cm}$, while the least $\mathrm{Mg}^{2+}$ value of 1.97 was recorded at $0-30 \mathrm{~cm}$ respectively. Analysis of variance of $\mathrm{Mg}^{2+}$ contents of flooded and upland area showed no significant difference at $\mathrm{p}>0.05$.

\subsection{8. $\mathrm{Na}^{+}$In Sampled Soils from Flooded and Upland Area inYola North LGA}

Results of values of sodium $\left(\mathrm{Na}^{+}\right)$level in the sampled soils from flooded and upland area in Yola-North LGA are presented in Table 3. In the flooded area, the highest and the least $\mathrm{Na}^{+}$values of $0.13 \mathrm{Cmolkg}^{-1}$ and $_{0.08} \mathrm{Cmolkg}^{-1}$ were recorded at $30-60 \mathrm{~cm}$ and $0-30 \mathrm{~cm}$ respectively. Location wise, the $\mathrm{Na}^{+}$value of $0.14 \mathrm{Cmolkg}^{-1}$ was recorded at Jambutu (L1), while the least $\mathrm{Na}^{+}$value of $0.11 \mathrm{Cmolkg}^{-1}$ was recorded at Runde-Baru (L2). Likewise, in the upland area of the same LGA, the values of $\mathrm{Na}^{+}$level in the sampled soils were generally higher than that of flooded area, with highest value of 0.57 $\mathrm{Cmolkg}^{-1}$ recorded at $0-39 \mathrm{~cm}$ depths, while least value of $0.13 \mathrm{Cmolkg}^{-1}$ was recorded at $60-90 \mathrm{~cm}$. In respect to location, Runde-Baru (L2) had the highest $\mathrm{Na}^{+}$value of $0.39 \mathrm{Cmolkg}^{-1}$, while Jambutu (L1) had least value of $0.36 \mathrm{Cmolkg}^{-1}$ respectively. Analysis of variances of the $\mathrm{Na}+$ contents of flooded and upland area showed no significant difference at $\mathrm{P}>0.05$

\subsection{9. $\mathrm{K}^{+}$in Sampled Soils from Flooded and Upland Area in Yola North LGA}

Results of values of $\mathrm{K}^{+}$found in the sampled soils from flooded and upland area in Yola-North LGA are presented in Table 3. In the flooded area of Yola-North LGA, the highest and the least $\mathrm{K}^{+}$values of $0.12 \mathrm{Cmolkg}^{-1} \mathrm{and}^{0.08} \mathrm{Cmolkg}^{-1}$ were recorded at $0-30 \mathrm{~cm}$ and $60-90 \mathrm{~cm}$ respectively. Location wise, Runde-Baru (L2) had the highest $\mathrm{K}^{+}$value of 0.11

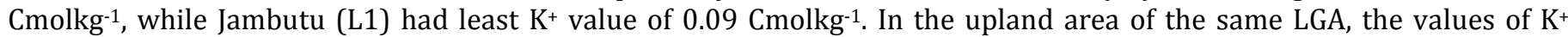
recorded across depths and location wise were generally higher than that of flooded area, with highest value of 0.67 cmolkg-1 recorded at $0-30 \mathrm{~cm}$, while least value $0.29 \mathrm{cmlkg}-1$ was recorded at $30-60 \mathrm{~cm}$ respectively. Location wise, Runde-Baru (L2) had the highest $\mathrm{K}^{+}$value of $0.51 \mathrm{Cmolkg}^{-1}$, while Jambutu (L1) had least $\mathrm{K}^{+}$value of $0.48 \mathrm{Cmolkg}^{-1}$. Analysis of variance of $\mathrm{K}^{+}$contents of flooded and upland area showed significant difference at $\mathrm{p}>0.05$.

\subsubsection{TEB in Sampled Soils from Flooded and Upland Area in Yola North LGA}

The results of total exchangeable base (TEB) found in the sampled soils from flooded and upland areas of YolaNorth LGA are presented in Table 3. In the flooded area, the highest and the least TEB values of $6.60 \mathrm{Cmolkg}^{-1}$ and 5.10 Cmolkg-1 were recorded at $60-90 \mathrm{~cm}$ and $0-30 \mathrm{~cm}$ respectively. With regard to location, the highest TEB value of 6.44 $\mathrm{Cmolkg}^{-1}$ was recorded at Runde-Baru (L2), while the least TEB value of $5.13 \mathrm{Cmolkg}^{-1}$ was recorded at Jambutu (L1). In the upland area of the same LGA, the TEB values recorded were generally higher across depths than that of flooded area, ranged between $8.01-8.08 \mathrm{Cmolkg}^{1}$. Likewise, across location, the highest and least TEB value of $8.01 \mathrm{Cmolkg}^{-1}$ and 7.93 $\mathrm{Cmolkg}^{-1}$ were recorded at Runde-Baru (L2) and Jambutu (L1) respectively. Analysis of variance of TEB contents of flooded and upland area showed significant difference at $\mathrm{p}<0.05$

\subsubsection{TEA in Sampled Soils from Flooded and Upland Area in Yola North LGA}

Results of total exchangeable acidity (TEA) found in the sampled soils from flooded and upland areas in YolaNorth LGA are presented in Table 3. In the flooded area, the highest and the least TEA values of $2.18 \mathrm{Cmolkg}^{-1}$ and 1.67 Cmolkg-1 were recorded at $30-60 \mathrm{~cm}$ and $60-90 \mathrm{~cm}$ respectively, while across the location wise, the highest TEA value of $2.23 \mathrm{Cmolkg}^{-1}$ was recorded at Jambutu (L1) and the least TEA value of $1.28 \mathrm{Cmolkg}^{-1}$ was recorded at Runde-Baru (L2). In the upland area of the same LGA, the highest and the least TEA values of $2.07 \mathrm{Cmolkg}^{-1}$ and $1.62 \mathrm{Cmolkg}^{-1}$ were recorded at $60-90 \mathrm{~cm}$ and $0-30 \mathrm{~cm}$ respectively. The highest TEA value of $2.00 \mathrm{Cmolkg}^{-1}$ was recorded at Runde-Baru (L2), while the least TEA value of $1.80 \mathrm{Cmolkg}^{-1}$ was recorded at Jambutu (L1). Analysis of variance of TEA contents of flooded and upland area showed no significant difference at $\mathrm{p}>0.05$.

\subsubsection{ECEC in Sampled Soils from Flooded and Upland Area in Yola North LGA}

The Results of ECEC found in the sampled soils from flooded and upland areas in Yola-North LGA are presented in

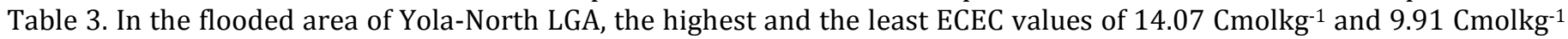
were recorded at $60-90 \mathrm{~cm}$ and $0-30 \mathrm{~cm}$ respectively. Location wise, the highest ECEC value of $13.08 \mathrm{Cmolkg}^{-1} \mathrm{was}^{-1}$ recorded at Runde-Baru (L2), while the least ECEC value of $10.46 \mathrm{Cmolkg}^{-1}$ was recorded at Jambutu (L1). In the upland area of the same LGA, the highest and the least ECEC values of $18.78 \mathrm{Cmolkg}^{-1}$ and $14.74 \mathrm{Cmolkg}^{-1}$ were recorded at $0-30$ $\mathrm{cm}$ and $60-90 \mathrm{~cm}$ respectively. Likewise, across location, the highest ECEC value of $18.34 \mathrm{Cmolkg}^{-1} \mathrm{was}^{\mathrm{recorded}}$ at Runde-Baru (L2), while the least ECEC value of $17.94 \mathrm{Cmolkg}^{-1}$ was recorded at Jambutu (L1). Analysis of variance of ECEC contents of flooded and upland area showed no significant difference at $\mathrm{p}>0.05$.

\subsubsection{PBS in Sampled Soils from Flooded and Upland Area in Yola North LGA}

Results of PBS found in the sampled soils from flooded and upland areas in Yola-North LGA are presented in Table 3. In the flooded area, the highest and the least PBS values of $75.06 \%$ and $70.03 \%$ were recorded at $60-90 \mathrm{~cm}$ and $0-30$ $\mathrm{cm}$ respectively. Location wise, the highest PBS value of $73.29 \%$ was recorded at Runde-Baru (L2), while the least PBS value of $72.70 \%$ was recorded at Jambutu (L1). In the upland area of the same LGA, the highest and the least PBS values of $79.55 \%$ and $75.89 \%$ were recorded at $0-30 \mathrm{~cm}$ and $60-90 \mathrm{~cm}$ respectively. Likewise, the highest PBS value of $79.33 \%$ was recorded at Runde-Baru (L2), while the least PBS value of $74.94 \%$ was recorded at Jambutu (L1). Analysis of variance of PBS contents of flooded and upland area showed significant difference at $\mathrm{p}<0.05$. 


\begin{tabular}{|c|c|c|c|c|c|c|c|c|c|c|c|c|c|}
\hline & $\frac{\pi}{2}$ & 㽞 & Oِ & $z \frac{\sqrt{80}}{\frac{80}{00}}$ & 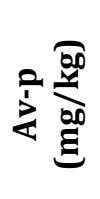 & 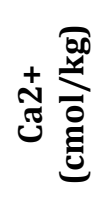 & 窇 & + & 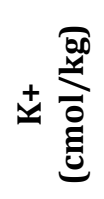 & 窇 & & 兽 & 虫 \\
\hline \multicolumn{14}{|c|}{ Flood AreaDepths } \\
\hline $\begin{array}{l}\stackrel{p}{2} \\
0\end{array}$ & 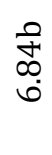 & $\stackrel{\pi}{\leftrightarrows}$ & 疍 & & 峁 & $\underset{m}{\stackrel{m}{+*}}$ & $\begin{array}{l}\stackrel{\pi}{2} \\
\text { ñ } \\
\text { n் }\end{array}$ & $\begin{array}{l}00 \\
0 \\
0 \\
0\end{array}$ & $\stackrel{\stackrel{\pi}{7}}{\overparen{0}}$ & $\begin{array}{l}\text { 울 } \\
\text { 궁 }\end{array}$ & $\begin{array}{l}\stackrel{0}{0} \\
\stackrel{\sim}{0} \\
\text { in }\end{array}$ & 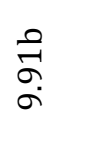 & $\begin{array}{l}\pi \\
\stackrel{0}{0} \\
\stackrel{1}{1}\end{array}$ \\
\hline $\begin{array}{l}0 \\
0 \\
\dot{m} \\
\text { }\end{array}$ & $\begin{array}{l}0 \\
0 \\
0 \\
\end{array}$ & 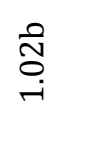 & $\begin{array}{l}\text { 음 } \\
\text { नैं }\end{array}$ & $\begin{array}{l}\stackrel{0}{0} \\
\stackrel{0}{\infty} \\
-i\end{array}$ & $\begin{array}{l}\stackrel{0}{\hat{0}} \\
\infty \\
\infty\end{array}$ & $\begin{array}{l}\text { ڤి } \\
0 \\
0\end{array}$ & 㟐 & $\stackrel{\stackrel{\pi}{m}}{\stackrel{0}{0}}$ & $\begin{array}{l}\infty \\
\stackrel{0}{0} \\
0 \\
0\end{array}$ & $\begin{array}{l}\vec{\sim} \\
\text { in }\end{array}$ & 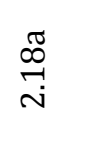 & $\begin{array}{l}\stackrel{\pi}{\stackrel{m}{*}} \\
\stackrel{m}{\sim}\end{array}$ & $\begin{array}{l}\ddot{n} \\
\stackrel{0}{0} \\
\ddot{R}\end{array}$ \\
\hline $\begin{array}{l}8 \\
\vdots \\
0 \\
0\end{array}$ & $\begin{array}{l}\stackrel{0}{\circ} \\
\stackrel{0}{6}\end{array}$ & $\stackrel{\widetilde{\pi}}{\underset{\sim}{ت}}$ & $\begin{array}{l}\overrightarrow{7} \\
\overrightarrow{6}\end{array}$ & : & 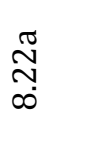 & $\underset{\infty}{\stackrel{\pi}{7}}$ & $\begin{array}{l}\stackrel{\pi}{\stackrel{n}{\circ}} \\
\text { m }\end{array}$ & $\stackrel{\pi}{\leftrightarrows}$ & $\begin{array}{l}0 \\
\stackrel{7}{0} \\
0\end{array}$ & $\begin{array}{l}\sigma \\
0 \\
0 \\
0 \\
0\end{array}$ & $\underset{-}{\stackrel{0}{\hat{\sigma}}}$ & $\begin{array}{l}\frac{\pi}{0} \\
\stackrel{0}{0} \\
\stackrel{+}{+}\end{array}$ & $\begin{array}{l}\text { 능 } \\
\text { 솟 }\end{array}$ \\
\hline$\sum_{\text {苫 }}$ & के & $\begin{array}{l}0 \\
\dot{m} \\
0 \\
0\end{array}$ & $\begin{array}{l}\text { Iै } \\
\stackrel{0}{0}\end{array}$ & $\begin{array}{l}\text { Ĩ } \\
\stackrel{0}{0}\end{array}$ & $\stackrel{\vec{H}}{\stackrel{7}{0}}$ & $\begin{array}{l}\overrightarrow{0} \\
0 \\
0 \\
0\end{array}$ & $\begin{array}{l}\stackrel{+}{0} \\
\text { N̦ }\end{array}$ & $\begin{array}{l}0 \\
\dot{0} \\
\dot{0}\end{array}$ & $\stackrel{m}{m}$ & 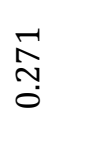 & 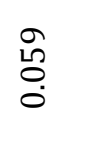 & $\underset{N}{\stackrel{N}{N}}$ & $\begin{array}{l}\underset{\mathrm{U}}{-} \\
\stackrel{-}{-}\end{array}$ \\
\hline $\begin{array}{l}\text { Zू } \\
0^{\circ}\end{array}$ & 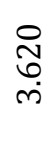 & $\begin{array}{l}\mathscr{M} \\
\infty \\
\dot{\forall}\end{array}$ & 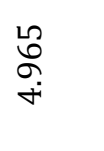 & 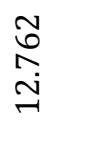 & $\begin{array}{l}\stackrel{-}{0} \\
\text { m. } \\
\end{array}$ & 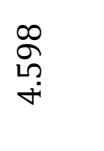 & $\underset{\stackrel{\mathscr{N}}{N}}{\stackrel{m}{\sim}}$ & $\begin{array}{l}\stackrel{\text { L }}{+} \\
\text { m. } \\
\stackrel{-}{\sim}\end{array}$ & $\begin{array}{l}\stackrel{\sim}{N} \\
\underset{N}{N}\end{array}$ & $\underset{N}{\stackrel{N}{N}}$ & 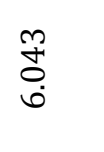 & 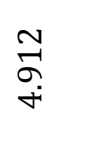 & 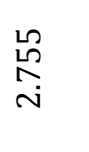 \\
\hline \multicolumn{14}{|c|}{ Location } \\
\hline$\exists$ & 究 & $\begin{array}{l}\text { o } \\
\text { Oे } \\
-i\end{array}$ & $\begin{array}{l}\text { ̊े } \\
\text { ָ̦ }\end{array}$ & $\begin{array}{l}\stackrel{\pi}{0} \\
\stackrel{1}{h} \\
\rightarrow-1\end{array}$ & 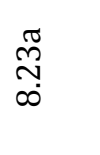 & 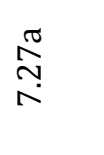 & 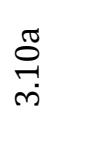 & $\stackrel{\pi}{\stackrel{\pi}{-1}}$ & $\stackrel{\pi}{\stackrel{\pi}{7}}$ & $\begin{array}{l}\vec{m} \\
\stackrel{\vec{H}}{\text { in }}\end{array}$ & $\underset{\sim}{\stackrel{N}{N}}$ & \begin{tabular}{l}
0 \\
\multirow{0}{0}{} \\
$\stackrel{0}{0}$
\end{tabular} & $\begin{array}{l}\stackrel{\pi}{2} \\
\stackrel{N}{N}\end{array}$ \\
\hline $\mathcal{I}$ & 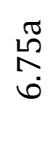 & $\stackrel{\sigma}{\stackrel{\sigma}{0}}$ & 艿 & 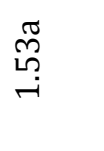 & 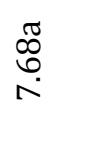 & $\begin{array}{l}\frac{\pi}{0} \\
\stackrel{0}{N}\end{array}$ & $\begin{array}{l}\stackrel{\pi}{+} \\
\dot{m}\end{array}$ & 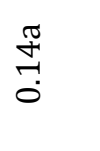 & $\begin{array}{l}\frac{\pi}{0} \\
\stackrel{0}{0}\end{array}$ & $\stackrel{\frac{\pi}{4}}{\stackrel{+}{6}}$ & 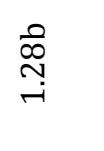 & $\begin{array}{l}\pi \\
\infty \\
0 \\
\stackrel{9}{\sim} \\
\sim\end{array}$ & $\begin{array}{l}\stackrel{\pi}{9} \\
\stackrel{N}{N}\end{array}$ \\
\hline$\sum_{\text {liv }}$ & 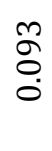 & $\begin{array}{l}\hat{o} \\
0 \\
0\end{array}$ & $\begin{array}{l}\infty \\
\tilde{m} \\
0 \\
0\end{array}$ & $\begin{array}{l}\stackrel{2}{\circ} \\
\stackrel{0}{0} \\
0\end{array}$ & $\begin{array}{l}\infty \\
\stackrel{\infty}{\sigma} \\
\stackrel{0}{0}\end{array}$ & $\begin{array}{l}\text { Oै } \\
\text { ?. } \\
0\end{array}$ & 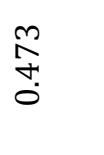 & $\begin{array}{l}\infty \\
\stackrel{\infty}{0} \\
0 \\
0\end{array}$ & $\begin{array}{l}m \\
\stackrel{0}{0} \\
0\end{array}$ & $\begin{array}{l}\stackrel{L}{L} \\
\stackrel{2}{0} \\
0\end{array}$ & $\begin{array}{l}\text { Iै } \\
\text { O̊ }\end{array}$ & $\stackrel{\sim}{\tilde{m}}$ & $\begin{array}{l}\hat{\imath} \\
\text { 己̊ } \\
0\end{array}$ \\
\hline 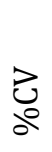 & 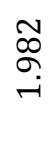 & 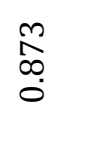 & مִ & $\begin{array}{l}\mathscr{0} \\
\stackrel{0}{+} \\
+\end{array}$ & $\begin{array}{l}\infty \\
\stackrel{\infty}{0} \\
\sim \\
m\end{array}$ & 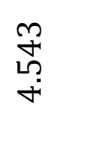 & $\begin{array}{l}0 \\
\stackrel{1}{0} \\
\stackrel{0}{0} \\
\sim\end{array}$ & $\begin{array}{l}\stackrel{+}{m} \\
\stackrel{\text { ஸे }}{N}\end{array}$ & $\begin{array}{l}0 \\
\circ \\
\text { ำ } \\
\text { ને }\end{array}$ & 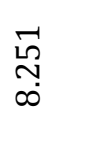 & $\begin{array}{l}8 \\
\stackrel{+}{+} \\
i\end{array}$ & $\begin{array}{l}-1 \\
\text { ஸे }\end{array}$ & $\stackrel{\overbrace{}}{\stackrel{\overbrace{}}{\sim}}$ \\
\hline \multicolumn{14}{|c|}{ Upland AreaDepths } \\
\hline $\begin{array}{l}m \\
\text { m }\end{array}$ & 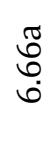 & $\begin{array}{l}\text { T⿱ } \\
\stackrel{+}{+}\end{array}$ & 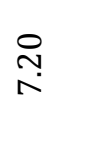 & 뉴 & 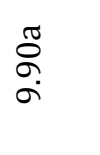 & $\begin{array}{l}\stackrel{\sigma}{\sigma} \\
\stackrel{-}{\sigma}\end{array}$ & 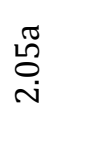 & 音 & 疍 & $\begin{array}{l}\infty \\
\stackrel{0}{0} \\
\infty \\
\infty\end{array}$ & & $\begin{array}{l}\pi \\
\infty \\
\infty \\
\infty \\
\sim\end{array}$ & 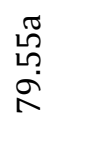 \\
\hline
\end{tabular}




\begin{tabular}{|c|c|c|c|c|c|c|c|c|c|c|c|c|c|}
\hline & $\frac{\pi}{2}$ & 采 & مِ & 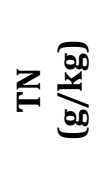 & 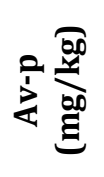 & 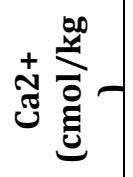 & 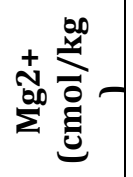 & 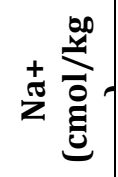 & 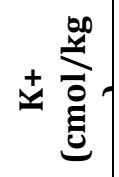 & 舀 & 凷 & 突 & 思 す \\
\hline 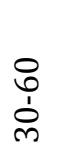 & 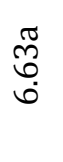 & $\begin{array}{l}\pi \\
\stackrel{8}{+} \\
-\end{array}$ & $\begin{array}{l}\stackrel{L}{\infty} \\
\stackrel{\infty}{\Lambda}\end{array}$ & 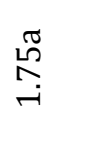 & 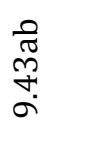 & 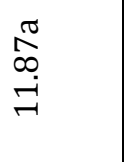 & $\stackrel{\sigma}{\stackrel{\sigma}{\sigma}}$ & $\stackrel{\stackrel{0}{~}}{\stackrel{0}{0}}$ & $\begin{array}{l}\stackrel{0}{\circ} \\
\text { m. } \\
0\end{array}$ & $\begin{array}{l}\stackrel{\pi}{0} \\
\stackrel{0}{0} \\
\infty\end{array}$ & $\stackrel{0}{\stackrel{7}{F}}$ & 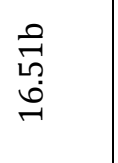 & $\begin{array}{l}\text { के } \\
\infty \\
\text { ம் } \\
\text { n. }\end{array}$ \\
\hline $\begin{array}{l}\text { ㅇ } \\
\text { ò }\end{array}$ & ف요 & $\begin{array}{l}\widetilde{\pi} \\
\stackrel{-}{-}\end{array}$ & 옴 & 욯 & $\begin{array}{l}\pi \\
0 \\
0 \\
0 \\
\sigma\end{array}$ & 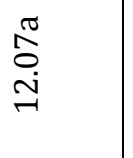 & $\begin{array}{l}\text { J } \\
\stackrel{0}{\circ}\end{array}$ & $\begin{array}{l}\ddot{m} \\
\stackrel{0}{0}\end{array}$ & 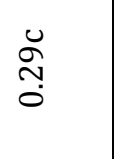 & $\begin{array}{l}\stackrel{\pi}{\pi} \\
\stackrel{\infty}{\infty} \\
\infty\end{array}$ & $\begin{array}{l}\stackrel{\sigma}{0} \\
\stackrel{\leftrightarrow}{N}\end{array}$ & $\begin{array}{l}\stackrel{U}{+} \\
\stackrel{+}{+}\end{array}$ & $\begin{array}{l}\pi \\
\infty \\
\infty \\
\infty \\
\infty\end{array}$ \\
\hline$\sum_{\text {空 }}$ & $\begin{array}{l}\hat{0} \\
\stackrel{0}{0}\end{array}$ & $\underset{0}{\tilde{O}}$ & 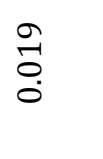 & $\begin{array}{l}0 \\
\stackrel{0}{0} \\
0\end{array}$ & $\begin{array}{l}\stackrel{0}{m} \\
\stackrel{\sim}{0}\end{array}$ & 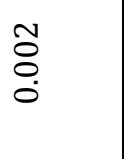 & $\frac{0}{\stackrel{1}{0}}$ & Oे & 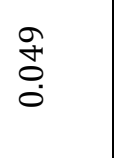 & $\frac{m}{\stackrel{2}{0}}$ & 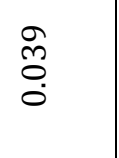 & $\begin{array}{l}\stackrel{0}{0} \\
\text { m. } \\
\stackrel{0}{0}\end{array}$ & $\stackrel{\text { Ln }}{\rightarrow}$ \\
\hline$\vec{\partial}$ & $\begin{array}{l}0 \\
\infty \\
\\
\end{array}$ & $\begin{array}{l}\stackrel{+}{\infty} \\
\stackrel{-}{-} \\
\rightarrow-\end{array}$ & 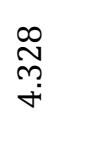 & 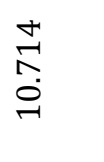 & $\underset{\sim}{\stackrel{N}{N}}$ & $\begin{array}{l}0 \\
\infty \\
0 \\
0 \\
0\end{array}$ & $\begin{array}{l}\text { oे } \\
\text { m. } \\
\stackrel{+}{+}\end{array}$ & $\begin{array}{l}\text { O } \\
\vdots \\
\text { å }\end{array}$ & 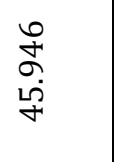 & $\begin{array}{l}\text { సે } \\
\text { ஸे }\end{array}$ & 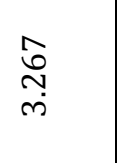 & 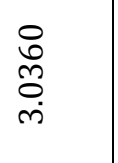 & ปี \\
\hline \multicolumn{14}{|c|}{ Location } \\
\hline$\exists$ & ف̊ & $\underset{\text { ָे }}{\text { - }}$ & $\stackrel{\circ}{\stackrel{9}{N}}$ & 莺 & $\begin{array}{l}\text { ஸீ } \\
\text { } \\
\text { a }\end{array}$ & 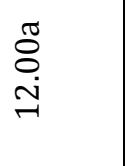 & 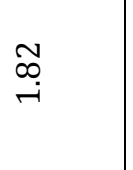 & م్ & 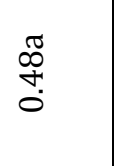 & $\begin{array}{l}\tilde{N} \\
\end{array}$ & & $\begin{array}{l}\frac{\pi}{+} \\
\stackrel{\sigma}{-}\end{array}$ & 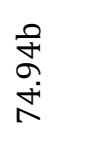 \\
\hline$\cong$ & ర్రి & $\stackrel{-\sigma}{-i}$ & శై & مึ & $\begin{array}{l}\text { ల్ } \\
\text { m. } \\
\text { a. }\end{array}$ & $\begin{array}{l}\stackrel{\pi}{0} \\
\stackrel{0}{0} \\
\stackrel{-}{-}\end{array}$ & $\underset{\text { ָ̦ }}{\text { Ni }}$ & 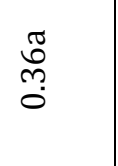 & 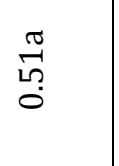 & $\begin{array}{l}\frac{\pi}{0} \\
\stackrel{\infty}{\infty}\end{array}$ & 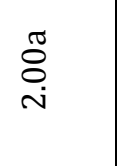 & 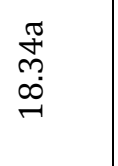 & $\begin{array}{l}\tilde{m} \\
m \\
\stackrel{R}{ }\end{array}$ \\
\hline$\sum_{\text {空 }}$ & $\begin{array}{l}\hat{o} \\
\text { o }\end{array}$ & $\begin{array}{l}\stackrel{2}{\circ} \\
\stackrel{0}{0} \\
0\end{array}$ & \begin{tabular}{l}
\multirow{0}{0}{} \\
$\stackrel{0}{0}$
\end{tabular} & $\stackrel{1}{0}$ & 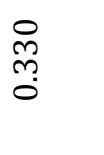 & 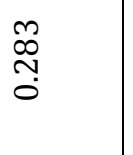 & $\stackrel{\stackrel{L}{N}}{\underset{0}{0}}$ & $\begin{array}{l}\hat{O} \\
\text { O̊. } \\
0\end{array}$ & $\begin{array}{l}\infty \\
\stackrel{0}{0} \\
0\end{array}$ & $\begin{array}{l}\stackrel{m}{N} \\
\text { חִ } \\
0\end{array}$ & $\begin{array}{l}\hat{0} \\
0 \\
0\end{array}$ & $\begin{array}{l}8 \\
0 \\
0 \\
0\end{array}$ & $\begin{array}{l}\hat{\sigma} \\
\stackrel{ }{\rightarrow}\end{array}$ \\
\hline 己̇ & $\stackrel{\text { I }}{\stackrel{5}{0}}$ & \begin{tabular}{l}
\multirow{2}{0}{} \\
0 \\
0
\end{tabular} & 先 & $\begin{array}{l}0 \\
\infty \\
\infty \\
0 \\
\ddots \\
-1\end{array}$ & $\begin{array}{l}\text { m } \\
\text { mె } \\
\text { ம் }\end{array}$ & 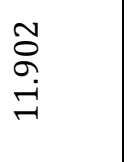 & $\begin{array}{l}\stackrel{0}{\sim} \\
\underset{\sigma}{0}\end{array}$ & $\begin{array}{l}\text { o } \\
\infty \\
\text { ஸे } \\
\text { N }\end{array}$ & 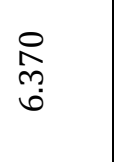 & 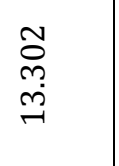 & 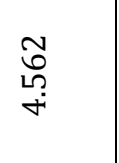 & $\begin{array}{l}\text { nै } \\
\sigma \\
0 \\
-1\end{array}$ & $\begin{array}{l}0 \\
\stackrel{0}{7} \\
\stackrel{\sim}{i}\end{array}$ \\
\hline $\begin{array}{l}\frac{0}{3} \\
\frac{\pi}{\pi} \\
\stackrel{1}{1} \\
2\end{array}$ & $\begin{array}{l}\infty \\
\stackrel{\infty}{0} \\
0 \\
0\end{array}$ & $\stackrel{\stackrel{L}{)}}{\stackrel{0}{0}}$ & $\begin{array}{l}\tilde{0} \\
0 \\
0\end{array}$ & $\begin{array}{l}\mathscr{\sigma} \\
\ddot{\infty} \\
\infty \\
0\end{array}$ & $\begin{array}{l}\vec{H} \\
\\
0\end{array}$ & 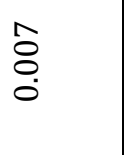 & $\begin{array}{l}\stackrel{0}{+} \\
\hat{0}\end{array}$ & $\underset{N}{N}$ & $\begin{array}{l}\hat{0} \\
0 \\
0\end{array}$ & $\begin{array}{l}\hat{0} \\
\stackrel{0}{0}\end{array}$ & \begin{tabular}{l}
$\infty$ \\
\multirow{0}{0}{} \\
$\stackrel{0}{0}$
\end{tabular} & $\begin{array}{l}\hat{o} \\
0 \\
0\end{array}$ & $\begin{array}{l}0 \\
\tilde{O} \\
0 \\
0\end{array}$ \\
\hline
\end{tabular}

Table 2: Chemical Properties of the Flooded and Upland Area in Yola-North LGA L1 \&L2 at Yola-North Are Jambutuand Runde-BaruRespectively Source: Field Survey (2020)

\subsection{Correlational Analysis of Physical and Chemical Properties of Flooded and Upland Soils in Yola-North Local Government} Area

\subsubsection{Correlational Analysis of Physical Properties of Flooded and Upland Soil in Yola-North LGA}

The results on relational analysis of physical properties of flooded and upland area in Yola-North LGA are presented in the Tables 3 and 4 respectively. The results in Table 3 shows that Clay property inversely related with Sand (r $=-0.79)$ but, related strongly with Silt $(r=0.75)$. Also, the bulk density related strongly with Sand $(r=0.88)$ and related strongly but negatively with silt $(\mathrm{r}=-0.61)$ and Clay $(\mathrm{r}=-0.92)$ respectively. Porosity related strongly but inversely with Sand $(r=-0.88)$ and Bulk Density $(r=-0.94)$, but related strongly with Silt $(r=0.59)$ and Clay $(r=0.97)$. 
The results in Table 4 reveal the correlational analysis among the physical properties of upland soil samples from Yola-North LGA. The results established a significant but inversely relation between silt and sand $(\mathrm{r}=-0.91)$. Likewise, Clay properties inversely related with Sand $(r=-0.93)$. The relationship among bulk density and other properties showed that bulk density related strongly with sand $(r=0.95)$, but related negatively with Silt $(r=-0.79)$ and with Clay ( $r=-0.94)$. The Soil porosity for the upland soil sample in Yola-North, related inversely with Sand $(r=-0.91)$ and Bulk Density ( $\mathrm{r}=-0.92)$. However, the porosity properties showed similar increased trend with Silt $(r=0.78)$ and Clay $(r=0.51)$ respectively.

\begin{tabular}{|c|c|c|c|c|c|}
\hline Properties & Sand & Silt & Clay & Bd & Porosity \\
\hline Sand & 1 & & & & \\
\hline Silt & -0.28 & 1 & & & \\
\hline Clay & $-0.79^{*}$ & $0.75^{*}$ & 1 & & \\
\hline Bd & $0.88^{*}$ & $-0.61^{*}$ & $-0.92^{*}$ & 1 & \\
\hline Porosity & $-0.88^{*}$ & $0.59^{*}$ & $0.97^{*}$ & $-0.94^{*}$ & 1 \\
\hline
\end{tabular}

Table 3: Correlational Analysis of Physical Properties of Flooded Area in Yola-North

*. Correlation is significant at the 0.05 level (2-tailed). Source: Field Survey, 2020

\begin{tabular}{|c|c|c|c|c|c|}
\hline & Sand & Silt & Clay & Bd & Porosity \\
\hline Sand & 1 & & & & \\
\hline Silt & $-0.91^{*}$ & 1 & & & \\
\hline Clay & $-0.93^{*}$ & 0.02 & 1 & & \\
\hline Bd & $0.95^{*}$ & $-0.79^{*}$ & $-0.94^{*}$ & 1 & 1 \\
\hline Porosity & $-0.91^{*}$ & $0.78^{*}$ & $0.51^{*}$ & $-0.92^{*}$ & \\
\hline
\end{tabular}

Table 4: Correlational Analysis of Physical Properties of Upland Area in Yola-North

*. Correlation Is Significant at the 0.05 Level (2-Tailed). Source: Field Survey, 2020

\subsubsection{Correlational Analysis of Chemical Properties of Flooded and Upland Soil in Yola-North LGA}

The results of correlation analysis among the chemical properties of flooded and upland soil samples from YolaNorth LGAs are presented in the Tables 5 and 6 respectively. The results in Table 5 established that EC related strongly with $\mathrm{pH}(\mathrm{r}=0.86)$, while TN (total Nitrogen) had negative relation with $\mathrm{pH}(\mathrm{r}=-0.65)$. The Av-P related strongly with $\mathrm{pH}$ $(\mathrm{r}=0.50)$. The $\mathrm{Mg}^{2+}$ related strongly with $\mathrm{pH}(\mathrm{r}=0.69), \mathrm{O} . \mathrm{C}(\mathrm{r}=0.63)$ and $\mathrm{Ca}^{2+}(\mathrm{r}=0.77)$. More so, $\mathrm{Na}^{+}$showed strong but inverse relationship with $\mathrm{Ca}^{2+}(\mathrm{r}=-0.55) . \mathrm{K}^{+}$related strongly with $0 . \mathrm{C}(\mathrm{r}=0.58)$ and $\mathrm{Ca}^{+}(\mathrm{r}=0.57)$ but weakly related with $\mathrm{Na}^{+}(\mathrm{r}=0.46)$. TEB related strongly with $\mathrm{pH}(\mathrm{r}=0.57)$, EC $(\mathrm{r}=0.70)$ and $\mathrm{Mg}^{2+}(\mathrm{r}=0.95)$ but inversely related with Ca ${ }^{2+}(\mathrm{r}=$ -0.55). TEA inversely related with 0.C $(\mathrm{r}=-0.74)$ but strongly related with $\mathrm{CA}^{2+}(\mathrm{r}=0.83)$. The ECEC related strongly with $\mathrm{pH}(\mathrm{r}=0.60)$, EC $(\mathrm{r}=0.73), \mathrm{Mg}^{2+}(\mathrm{r}=0.86)$ and TEB $(\mathrm{r}=0.89)$. The PBS related strongly with $0 . \mathrm{C}(\mathrm{r}=0.60), \mathrm{Mg}^{2+}(\mathrm{r}=0.53)$ and TEB $(r=0.59)$, whereas, the relationship that exist between PBS and TEA was inversely significant $(r=-0.91)$.

The results of correlation analysis among chemical properties of samples soils from upland area in Yola-North LGA are presented in Table 6. The results established weak and inversely relationship between 0.C and EC $(\mathrm{r}=-0.44)$. The TN related strongly but negatively with $\mathrm{pH}(\mathrm{r}=-0.51)$ and related positively but weakly with EC. Av-P related weakly with $\mathrm{pH}(\mathrm{r}=0.40)$. It also related weakly but inversely with $\mathrm{TN}(\mathrm{r}=-0.49)$. The relationship between $\mathrm{Mg}^{2+}$ and other soil chemical properties showed that $\mathrm{Mg}^{2+}$ related strongly with $\mathrm{pH}(\mathrm{r}=0.62)$ but related inversely with $\mathrm{Ca}^{2+}(\mathrm{r}=-0.67)$. The TEB related strongly with $\mathrm{pH}(\mathrm{r}=0.61), \mathrm{Ca}^{2+}(\mathrm{r}=0.87)$ and $\mathrm{Mg}^{2+}(\mathrm{r}=0.86)$. The TEA related weakly with $\mathrm{pH}(\mathrm{r}=0.40)$ and strongly related with Av-P $(\mathrm{r}=0.56)$. The ECEC related strongly with $\mathrm{pH}(\mathrm{r}=0.72), \mathrm{Ca}^{2+}(\mathrm{r}=0.71), \mathrm{Mg}^{2+}(\mathrm{r}=0.84)$ and TEB $(r=0.91)$. PBS related strongly with $\mathrm{Ca}^{2+}(\mathrm{r}=0.65)$, TEB $(\mathrm{r}=0.57)$ and inversely with TEA $(r=-0.80)$.

\begin{tabular}{|c|c|c|c|c|c|c|c|c|c|c|c|c|c|}
\hline & $\bar{a}$ & ب & ب. & $z$ & $\sum^{2}$ & $\stackrel{+}{\mathbb{J}}$ & 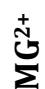 & $\stackrel{+}{\Sigma}$ & \pm & $\stackrel{\infty}{\underline{T}}$ & $\underset{F}{\mathbb{r}}$ & بئِ & $\mathscr{a}$ \\
\hline $\mathrm{PH}$ & -1 & & & & & & & & & & & & \\
\hline EC & 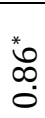 & - & & & & & & & & & & & \\
\hline O.C & $\stackrel{m}{\circ}$ & 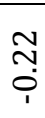 & - & & & & & & & & & & \\
\hline TN & 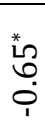 & $\begin{array}{l}\text { ने } \\
\text { i. }\end{array}$ & 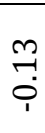 & -1 & & & & & & & & & \\
\hline
\end{tabular}




\begin{tabular}{|c|c|c|c|c|c|c|c|c|c|c|c|c|c|}
\hline & $\bar{\Omega}$ & ب্ & بٌ & $\underset{Z}{Z}$ & $\stackrel{p}{\frac{1}{2}}$ & $\stackrel{+}{\stackrel{N}{S}}$ & 芯 & $\stackrel{+}{z}$ & \pm & 睘 & 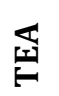 & بئ & 吆 \\
\hline AV-P & $\begin{array}{l}\text { *0 } \\
\text { ำ } \\
0\end{array}$ & ర్ & స̃ & $\begin{array}{l}\stackrel{0}{N} \\
\stackrel{0}{i}\end{array}$ & - & & & & & & & & \\
\hline CA2+ & 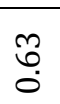 & ָָ & $\begin{array}{l}\text { Oे } \\
\text { o. }\end{array}$ & $\begin{array}{l}0 \\
0 \\
0\end{array}$ & $\begin{array}{l}\infty \\
\stackrel{0}{0} \\
0\end{array}$ & - & & & & & & & \\
\hline MG2+ & $\begin{array}{l}\text { *a } \\
\stackrel{0}{0} \\
0\end{array}$ & $\underset{N}{\tilde{O}}$ & $\begin{array}{l}\stackrel{*}{\tilde{\sigma}} \\
\stackrel{0}{0}\end{array}$ & $\begin{array}{l}\infty \\
\stackrel{\sim}{+} \\
\stackrel{1}{1}\end{array}$ & $\stackrel{m}{a}$ & 芵 & - & & & & & & \\
\hline $\mathrm{NA}+$ & $\stackrel{\infty}{\stackrel{1}{0}}$ & के & \begin{tabular}{l}
\multirow{N}{N}{} \\
$\stackrel{1}{1}$
\end{tabular} & 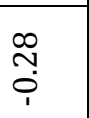 & $\begin{array}{l}\text { mे } \\
\text { ị }\end{array}$ & 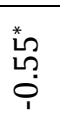 & $\begin{array}{l}\text { mి } \\
\text { ọ }\end{array}$ & - & & & & & \\
\hline $\mathrm{K}+$ & $\begin{array}{l}\hat{0} \\
0 \\
i\end{array}$ & $\begin{array}{l}\text { ò } \\
\text { in }\end{array}$ & $\begin{array}{l}\infty \\
\stackrel{1}{L} \\
0\end{array}$ & $\begin{array}{l}01 \\
0 \\
1\end{array}$ & $\begin{array}{l}\stackrel{0}{N} \\
\stackrel{0}{o}\end{array}$ & 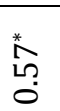 & $\begin{array}{l}\hat{N} \\
\text { ọ }\end{array}$ & $\begin{array}{l}0 \\
\stackrel{0}{0}\end{array}$ & $r$ & & & & \\
\hline TEB & 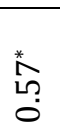 & $\begin{array}{l}\text { *0 } \\
\text { م }\end{array}$ & O̊. & $\begin{array}{l}\stackrel{+}{N} \\
\stackrel{1}{1}\end{array}$ & $\stackrel{\vec{H}}{\stackrel{2}{0}}$ & 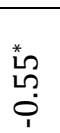 & $\begin{array}{l}\text { Ln } \\
\hat{\sigma} \\
0\end{array}$ & $\begin{array}{l}0 \\
\stackrel{1}{0} \\
\text { i. }\end{array}$ & ö & 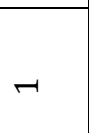 & & & \\
\hline TEA & $\begin{array}{l}0 \\
0 \\
0\end{array}$ & ন্. & , $\frac{t}{0}$ & , $\stackrel{0}{m}$ & , $\stackrel{\ln }{m}$ & $\begin{array}{l}\text { m } \\
\infty \\
0 \\
0 .\end{array}$ & , $\begin{array}{l}\sigma \\
0 \\
0\end{array}$ & $\stackrel{+}{a}$ & , & , ָָ & $-r$ & & \\
\hline ECEC & $\begin{array}{l}\text { *0 } \\
\stackrel{0}{0} \\
0\end{array}$ & 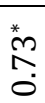 & $\begin{array}{l}\infty \\
\stackrel{\infty}{N} \\
\stackrel{p}{1}\end{array}$ & 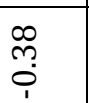 & $\begin{array}{l}0 \\
0 \\
0 \\
1\end{array}$ & $\begin{array}{l}{ }^{*} \\
\text { ปñ? } \\
0\end{array}$ & $\begin{array}{l}\text { * } \\
\stackrel{0}{0} \\
0 \\
0\end{array}$ & $\begin{array}{l}+ \\
0 \\
0\end{array}$ & $\begin{array}{l}+ \\
0 \\
0\end{array}$ & $\begin{array}{l}\text { *a } \\
\stackrel{0}{0} \\
\stackrel{0}{0}\end{array}$ & 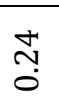 & $r$ & \\
\hline PBS & $\begin{array}{l}\text { of } \\
\text { o }\end{array}$ & न. & 華 & $\stackrel{\sigma}{\sigma}$ & ભి & $\begin{array}{l}0 \\
\stackrel{1}{0} \\
\stackrel{1}{1}\end{array}$ & $\begin{array}{l}\stackrel{*}{n} \\
\stackrel{\text { Lִ }}{0}\end{array}$ & $\underset{\stackrel{+}{+}}{\stackrel{+}{0}}$ & $\underset{\leftarrow}{\stackrel{+}{0}}$ & 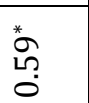 & 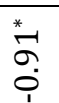 & 궁 & -1 \\
\hline
\end{tabular}

Table 5: Correlation Analysis of Chemical Properties of Flooded Area in Yola-North *. Correlation Is Significant at the 0.05 Level (2-Tailed)

Source: Field Survey, 2020

\begin{tabular}{|c|c|c|c|c|c|c|c|c|c|c|c|c|c|}
\hline & $\bar{a}$ & ư & بِ & $Z$ & $\frac{1}{4}$ & $\stackrel{+}{\stackrel{U}{U}}$ & $\stackrel{+}{\mathrm{J}}$ & $\frac{+}{z}$ & \pm & 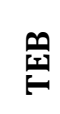 & $\underset{్}{\mathbb{1}}$ & بئ & $\mathscr{m}$ \\
\hline $\mathrm{PH}$ & - & & & & & & & & & & & & \\
\hline EC & 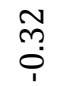 & -1 & & & & & & & & & & & \\
\hline O.C & $\stackrel{\Delta}{0}$ & $\begin{array}{l}\stackrel{+}{*} \\
\stackrel{0}{0}\end{array}$ & - & & & & & & & & & & \\
\hline $\mathrm{TN}$ & 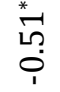 & $\underset{0}{+}$ & & - & & & & & & & & & \\
\hline AV-P & 웅. & $\begin{array}{l}0 \\
\stackrel{0}{0} \\
1\end{array}$ & ఠ。 & & - & & & & & & & & \\
\hline $\mathrm{CA} 2+$ & $\underset{+}{\stackrel{F}{0}}$ & $\begin{array}{l}\hat{N} \\
\text { ì }\end{array}$ & $\begin{array}{l}0 \\
-1 \\
0 \\
1\end{array}$ & $\begin{array}{l}m \\
\stackrel{2}{0}\end{array}$ & $\begin{array}{l}0 \\
0 \\
\end{array}$ & - & & & & & & & \\
\hline MG2+ & 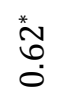 & $\begin{array}{l}\tilde{O} \\
0\end{array}$ & $\begin{array}{l}\text { mे } \\
\text { ô }\end{array}$ & 훙 & $\begin{array}{l}0 \\
\stackrel{1}{1} \\
\text { in }\end{array}$ & 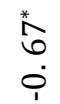 & -1 & & & & & & \\
\hline NA+ & $\stackrel{\circ}{\circ}$ & $\begin{array}{l}\infty \\
0 \\
0\end{array}$ & $\underset{N}{0}$ & $\begin{array}{l}\stackrel{0}{N} \\
0\end{array}$ & $\underset{\sim}{\text { N }}$ & $\begin{array}{l}\text { Lo } \\
0 \\
0\end{array}$ & $\begin{array}{l}0 \\
\stackrel{1}{0}\end{array}$ & -1 & & & & & \\
\hline
\end{tabular}




\begin{tabular}{|c|c|c|c|c|c|c|c|c|c|c|c|c|c|}
\hline & $\bar{I}$ & ư & بّ & Z & $\frac{1}{2}$ & $\stackrel{+}{\stackrel{ \pm}{J}}$ & $\stackrel{+}{\text { U }}$ & $\sum_{z}^{+}$ & $\stackrel{+}{ \pm}$ & $\frac{\varphi}{\mid r y}$ & 䛢 & 式 & $\tilde{m}$ \\
\hline $\mathrm{K}+$ & $\stackrel{\text { mె}}{0}$ & $\begin{array}{l}m \\
0 \\
0\end{array}$ & $\stackrel{ }{\stackrel{-}{0}}$ & $\stackrel{\sim}{\overparen{\sim}}$ & $\stackrel{\infty}{\stackrel{\infty}{*}}$ & $\begin{array}{l}\infty \\
\stackrel{\circ}{0} \\
\stackrel{0}{0}\end{array}$ & $\begin{array}{l}\text { L } \\
\circ\end{array}$ & 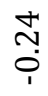 & - & & & & \\
\hline TEB & 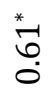 & 음 & $\begin{array}{l}0 \\
\stackrel{0}{0} \\
\stackrel{1}{1}\end{array}$ & $\stackrel{\sigma}{\circ}$ & $\begin{array}{l}1 \\
0 \\
0\end{array}$ & $\begin{array}{l}{ }_{\infty}^{*} \\
0 \\
0\end{array}$ & $\begin{array}{l}\underbrace{*} \\
\infty \\
0\end{array}$ & $\stackrel{7}{ }$ & 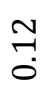 & - & & & \\
\hline TEA & $\stackrel{\circ}{\stackrel{0}{0}}$ & $\begin{array}{l}0 \\
\stackrel{1}{0} \\
0\end{array}$ & $\begin{array}{l}N \\
\stackrel{1}{1}\end{array}$ & $\begin{array}{l}\stackrel{0}{N} \\
\stackrel{1}{1}\end{array}$ & $\begin{array}{l}\text { 苂 } \\
\text { L̊ } \\
0\end{array}$ & مُ & $\stackrel{\infty}{\stackrel{\infty}{0}}$ & 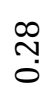 & $\stackrel{\sim}{\overparen{7}}$ & $\begin{array}{l}\text { Ō } \\
\text { O }\end{array}$ & -1 & & \\
\hline ECEC & $\stackrel{*}{N}$ & $\begin{array}{l}\infty \\
\stackrel{\infty}{0} \\
\end{array}$ & 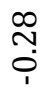 & $\begin{array}{l}\infty \\
0 \\
0\end{array}$ & $\stackrel{ }{\sigma}$ & 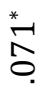 & $\begin{array}{l}\mathfrak{H}^{*} \\
\stackrel{\infty}{0} \\
0\end{array}$ & $\stackrel{\text { ָ̦ }}{0}$ & $\begin{array}{l}0 \\
\stackrel{1}{0}\end{array}$ & $\stackrel{*}{\sigma^{*}}$ & $\stackrel{+}{\leftarrow}$ & - & \\
\hline PBS & $\begin{array}{l}\infty \\
\circ \\
\circ\end{array}$ & $\begin{array}{l}\text { 농 } \\
\text { 우 }\end{array}$ & $\begin{array}{l}\hat{O} \\
0 \\
0\end{array}$ & $\begin{array}{l}\infty \\
\stackrel{\infty}{0} \\
0\end{array}$ & $\begin{array}{l}m \\
\dot{*} \\
\dot{1}\end{array}$ & $\begin{array}{l}\text { L̊ } \\
\text { مْ } \\
0\end{array}$ & 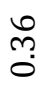 & $\frac{a}{2}$ & 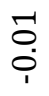 & 苚 & 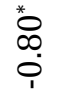 & $\stackrel{\infty}{\stackrel{\infty}{\sigma}}$ & - \\
\hline
\end{tabular}

Table 6: Correlation Analysis of Chemical Properties of Upland Area in Yola-North

*. Correlation Is Significant at the 0.05 Level (2-Tailed)

Source: Field Survey, 2020

\section{Discussion}

\subsection{Physical Properties of Flooded and Upland Soils in Yola-North LGAs}

The results of sand contents showed that in Yola-North Local Government Area, the upland area recorded more sand contents, which significantly differed with sand contents in the flooded area $(\mathrm{p}<0.05)$. This may be attributed to the high volume of flood water that eroded away some sand properties of the soil in both locations. This showed that there was high percolation rates and low capillary action at upland area as a result of minimal impact of running water at upland. This result agrees with the findings made by Ubuoh et al. (2016) that at flooded area there is always low percolation rate and high capillary action as a result of low sand property. Also, the current results are in accordance with that made by Kalshetty et al. (2012) that flooded area recorded significantly lower sand contents $(\mathrm{P}<0.05)$ compared to upland area.

Also, the overall results of silt contents in the flooded and upland area in Yola-North Local Government Area showed that the flooded area recorded more silt contents which is significantly higher than upland area at $\mathrm{P}<0.05$. This result agrees with that of Njoku and Okoro (2015) that silt contents was significantly higher in flooded area than upland areas.

The overall observation of the results showed that in Yola-North LGAs, the flooded area recorded more clay contents than upland area which is significant at $\mathrm{P}<0.05$. This could be as a result of the effect of flooded water that had washed away the sand property leaving behind more clay in the flood soils. This agrees with the conclusion drawn by Madueke et al. (2012) that in comparison, the flooded plain significantly had more clay than upland area. The results agree with respective findings made from studies by Daffi (2013) and Ekwue and Bartholomew (2010), which showed more clay at flooded area than upland area.

The results of the texture classes for the flooded and upland area in the Yola-North Local Government Area showed that in all locations and across depths, the sand texture classes were dominated by sandy clay, clay and loam respectively. The result is in line with the observation by Njoku and Okoro (2015), who stated that texture was a permanent component of the soil and did not change as much withtime.

The overall results of the bulk density contents of the flooded and upland area in the Yola North local government area showed that the bulk density contents generally lower across the depths in flooded area than upland area. However, the analysis of variance showed no significant difference at $p>0.05$. This agreed with the conclusion made by Dezzeo et al. (2010) that soil properties such as bulk density had a large influence on denitrification activities of flooded soils.

The Porosity in both the flooded area is higher significantly at $\mathrm{P}<0.05$ than in the upland for respective Yola-North LGAs s. This showed that the rate of infiltration and the water-holding capacity is higher at flood plains and lowest atupland area. This agreed with the findings made by Ubuoh et al. (2016) that soil physical properties such as porosity were poor during flooding and increase denitrification activities of the soil.

\subsection{Chemical Properties of Flooded and Upland Soils in Yola-North LGA}

The overall results of $\mathrm{pH}$ values in the flooded and upland soils from both Yola-North LGA, showed that pH values at flooded area were in the range $(6.68-6.84)$ which was slightly higher than range of values recorded at upland area, though, not significantly different at $p>0.05$. This conforms with the results obtained by Oviasogie and Omoruyi (2010) and Osman (2013). However, the $\mathrm{pH}$ values recorded at flooded area in this study were generally lower than that of 
Gebrelibanos and Assen (2013) and Daffi (2013), who recorded pH values that ranged between (6.9 - 75) for flood affected farmlands. The higher value of $\mathrm{pH}$ observed at flooding area in this study may not be unconnected with the effects of flooding waters which makes the $\mathrm{pH}$ value to approach neutrality. This agreed with the submission made by Daffi (2013) that after a soil is flooded regardless of its original $\mathrm{pH}$ before flooding, the $\mathrm{pH}$ would approach neutrality (6.5 to 7.5). The high $\mathrm{pH}$ value could also influence micronutrients, which thrived at expenses of soil wetness. This concurred with the conclusion drawn by Yakubu and Oganuya (2009) that soluble manganese (Mn) concentrations may "explode" in flooded soils, interfering with iron (Fe) nutrition and causing iron chlorosis, especially in flax. More so, Wall (2012) reported that the flooding of alkaline (high $\mathrm{pH}$ or high lime) soils causes a buildup of bicarbonate, which interferes with iron uptake and causes iron deficiency and chlorosis.

The results of the electrical conductivity (EC) in Yola-North LGA showed that the electrical conductivity of the flooded soils was slightly higher than that of upland soils, though, the result of analysis of variance indicated no significant difference $(p>0.05)$. Thus, the slight rise in the electrical conductivity of the soils could be attributed to the presence of flooding water. The increment in the EC of the flooded soils could be as a result of more moisture contents than upland soils. This agrees with the observation made by Njoku and Okoro (2015) that the moisture content of soils is significantly related to electrical conductivity. Likewise, studies by Timbal et al. (2011), Drogue et al. (2014) and Zhang et al. (2013) reported significant relationship between soil moisture contents and Electrical Conductivity (EC) in the soils.

The results of Organic Carbon (OC) in Yola-North LGA, showed that the Organic Carbon in the flooded area are generally lesser than that found in the upland area and showed significant difference at $\mathrm{P}<0.05$. The reduction in Organic Carbon in the flooded area could be as a result of bacterial decomposition or ration that took place after flooding effects in the study area. This concurs with the results of Steven and Cole (2011) that among the aftermath effects of the flood is bacterial decomposition which usually leads to reduction of Organic Carbon in flood affect area. Likewise, Fan, Hao and Malhi (2010) reported that there is always a slight reduction in total Organic Carbon observed in the flood affected farmlands, whichcould be due to the effect of flooding; as most soil organic content such as organic acids andhumus which are the sole source of Organic Carbon could have been leached out by the impact ofthe flood. In a nutshell, the decreased Organic Carbon content of soil could adversely affect soil quality and fertilitysince Organic Carbon is required to stimulate microbial respiration and activities. However, the reducedOrganic Carbon content in the flood affected area as found in this study is at variance with the findings of Kalshetty et al. (2012) whereincreased Organic Carbon content was observed in flood affected cultivated area in India.

The results of total nitrogen (TN) in Yola-North LGA, showed that the nitrogen values in both flooded and upland area ranged from $(1.35-1.80) \mathrm{g} / \mathrm{kg}$ and $(1.40-1.75) \mathrm{g} / \mathrm{kg}$ respectively which are not significantly different $(\mathrm{P}>0.05)$. However, this result is at variance with that of Njoku et al. (2011) where flooded area recorded significantly $(\mathrm{p}<0.05)$ higher nitrogen value than upland, which was reported to have accounted for rapid fruiting and ripening of fruiting as well as increased resistance in grains. The variant between current results of nitrogen value and that found by Njoku et al. (2011) may not be unconnected with variation in duration of flooding and flood water level in both studies.

The results of available phosphorus (Av-P) in Yola-North LGAs, showed that the value of available phosphorus in the flooded area were less than that of upland area which is significantly different at $\mathrm{P}<0.05$. The decrease in the values of available phosphorus in the flooded soils could be attributed to the effect of flood water as a result of leaching of available phosphorus as phosphate in the soil, since in water columns, anaerobic conditions render it soluble. However, the phosphorus reduction in the flood affected area is in strong contrast with the findings of Osakwe et al. (2014) where increased phosphorus levels were seen in flood affected cultivated soils in India. Likewise, the current finding of lower value of available phosphorus differed with that of Jeb and Aggarwal (2011) that observed increased available phosphorous in flooding area. Likewise, Obermann et al. (2009) observed gradual increases in the available phosphorus of the flooded soil and this increment was attributed to either the reduction or dissolution of iron and calcium phosphates, respectively. However, the study by Ruiz-Sinoga (2012) reported that increased available phosphorus will not necessarily lead to increased crop productivity after flooding because oxidation processes will return the phosphates to their original associations.

The results of the calcium $\left(\mathrm{Ca}^{2+}\right)$ value in Yola-North LGA showed that in the flooded area, the calcium reduced significantly at $\mathrm{P}<0.05$, than values of calcium found in upland area. This result agrees with the observation made by Clilverd et al. (2013) that flood affected soil properties, which includes exchangeable cations like calcium, the calcium content of soil reduces as the moisture content increase during flooding. This result is consistent with findings from previous studies (Amarawansha et al., 2015; Dezze et al. 2010).

The results of the magnesium $\left(\mathrm{Mg}^{2+}\right)$ values in the Yola-North LGA showed that the flooded area had less magnesium than in the upland area. Though, the results of analysis of variance indicated no significant difference $p>0.05$. However, the slight rise in the value of Magnesium can be attributed to the effect of flooding water. The increase in the value of magnesium as a result of flooding showed that flooding plays a part in healthy development since magnesium is among the essential micronutrientsrequired in the soil for improved soil productivity. The increased level of magnesium as reported in the study is in accordance with that reported by Shao (2010) where increasedlevels were seen in flood affected soils in India.

The results of the level of sodium $\left(\mathrm{Na}^{+}\right)$in the Yola-North LGA, showed that the flooded area had lesser sodium value than those found in the upland area, though not significantly different $(P>0.05)$. This result agrees with that of Shao (2010) that observed a low $\mathrm{Ca}, \mathrm{Mg}, \mathrm{K}$ and $\mathrm{Na}$ during high flood in his study which was attributed to leaching and dilution. Likewise, the study by Amarawansha et al. (2015) found decreased sodium level and argued that flooding increased the solubility of mineral nutrients which increased their chances of being reduced through leaching. It could be expected that 
during a high flood more soil nutrients dissolve in water and are lost through leaching as water infiltrates the soil. It could also be expected that because clay is negatively charged cations would bond to the soil particles, thus reducing leaching.

The results from this study showed that the level of potassium $\left(\mathrm{K}^{+}\right)$found in the flooded area of both the YolaNorth and South are significantly different $(\mathrm{p}<0.05)$ with those found in the upland area respectively. Generally, the potassium levels were lower in the flooded area when compare with those in the upland. Thus, the reduction in the value of potassium could be attributed to effect of flooding water. A high flood is expected to lead to anoxic conditions because of increased water depths and prolonged waterlogging, which leads to mobilization of Potassium and results in its increase. This agreed with the conclusion made by Diane et al (2016), that under aerobic conditions, Potassium binds to iron oxides and due to prolonged anaerobic conditions imposed by flooding, Fe bound to P is reduced fromFe (III) to Fe (II), releasing Potassium from iron-phosphate complexes 6,8, 54. Likewise, Connelly et al. (2015) expressed that it is expected that during low flooding conditions, Potassium reacts with $\mathrm{Ca}, \mathrm{Al}$ and $\mathrm{Fe}$ oxy-hydroxides as a result of aerobic conditions, consequently reducing its available content in the soil. However, potassium is among the macronutrient that is notonly required for healthy plant growth in the soil, but also for proper microbial functioning, therefore a reduction in potassium levels in the flood affected soils is a negative impact on soilquality.

The results on Total Exchangeable Base (TEB) found in Yola-North LGA, showed that in the flooded area, TEB values were generally lesser than those found in the upland area, with significance difference at $\mathrm{P}<0.05$. This result is in conformity with that of Rasmussen et al. (2010) that observed decreased value of TEB in the flooded plain along Niagara Falls in Canada. Likewise, the study by Bechtold and Naiman (2009) and Gervais-Beaulac (2013) indicated that the TEB reduces as flooding persists for longer periods.

However, the slightly higher values of TEA established that there was high rate of acidity in flood area compared to that in the upland area. This means that there is high rate of negative changes on organic matter in flooded soils. This finding agrees with that of Connelly et al. (2015) that observed that flooding affects the exchangeable acidity of soil due to its intensity. Also, studies by Bechtold and Naiman (2009) and Gervais-Beaulac (2013) indicated that there were significantly higher values of TEA in most sampled floodplains.

The results on Total Exchangeable Acidity (TEA) found in Yola-North LGA, showed that in the flooded area, TEA values were generally higher than those found in the upland area, though, the analysis of variance showed no significant difference $p>0.05$. However, the slightly higher values of TEA established that there is high rate of acidity in flood area compared to that in the upland area. This means that there is high rate of negative changes on organic matter in flooded soils. This finding agreed with that of Medeiros et al (2018) that observed that flooding affects the exchangeable acidity of soil due to its intensity. Also, studies by Shamshuddin et al. (2016) and Azuhan (2015) reported that there were significant higher values of TEA in most sampled floodplains.

The results of the Effective Cation Exchange Capacity (ECEC) from both Yola-North LGA showed that ECEC values from flooded and upland area were not significantly different. However, the ECEC in the flooded area was generally less than that of upland area and this could be as a result of reduction in the organic matter, usually experiences in the flood affected soil. This finding concurred with that made by Nurul-Akma et al. (2015) that lower ECEC indicated that there is high presence of negative charges on soil clays and organic matter in the flooded soil. Likewise, the finding by Connelly et al. (2015) attributed low ECEC to effect of reduced organic matter in the flood affected soils, which could also account for the reduction in cation exchange capacity, since organic matter contributes to the cation exchange capacity of the soil by increasing adsorption sites for cations. However, Panhwar et al. (2015) also found the reduction of ECEC in flooded farmlands, though they cautioned that reduced cation exchange capacity is not favorable for agricultural soil because it limits the availability of essential positively charged macro and micro nutrients to be absorbed on soil particles, since few negatively charged sites will be available to attract them. The fact that reduction in cation exchange capacity levels on the flood is likely to affect farmlands is similar to the findings of Shehu (2015) where reduced levels were also observed on flooding of cultivated area of Sudan Savanah region.

The results of the Percentage Base Saturation (PBS) found in Yola-North and LGA from flooded areas were generally less than that in the upland soils. However, the difference was not significant $(p>0.05)$. This result showed that there was loss in percentage base saturation during flooding. This agrees with the findings made by Shehu et al. (2015) that during flooding percentage base saturation decreases as water level increases and flooding takes longer period than usual. Likewise, Njoku et al. (2011) reported that percentage base saturation decreased as a result of flooding in Ebonyi River Basin, Nigeria.

\subsection{Correlational Analysis of Physical and Chemical Properties of Sampled Flooded and Upland Soils from Yola-North LGA, Adamawa State}

\subsubsection{Correlational Analysis among Physical Properties}

In overall, the correlation among the physical properties of soils in both flooded and upland area in Yola-North LGAs, showed that in the flood's samples, the clay properties indicate strong and significant relationship ( $<<0.05$ ), alongside with porosity, while in upland area, sand contents were found significantly related with bulk density. However, it was observed from flooded area that Sand and Silt did not show signification relation. This showed the impact of flooding effects on physical properties of sampled soils that tend to increase some properties than others across the study area. This agrees with findings made by Kefas et al. (2016) that as results of flood, some physical properties of soils tend to disproportionally increase than others. Likewise, the study by Weil and Brady (2016) indicated that there are high chances that flooding alter the physical properties of soils, where some will sharply rise above others. 


\subsubsection{Correlational Analysis among Chemical Properties}

The correlation among the chemical properties of flooded soils in the Yola-North LGAs revealed that chemical properties such as $\mathrm{pH}, \mathrm{Ca} 2+, \mathrm{Mg} 2+$, TN, TEB and EC show strong relationship at $\mathrm{p}<0.05$. Whereas, TEB, O.C, Na, TEA, AV-P and ECEC are strong but inversely related. However, these results differed with correlatonal analysis in the chemical properties of upland area in both Yola-North and South Local Government Area, where TEA and pH show strong relationship. Likewise, ECEC related strongly with $\mathrm{Ca} 2+, \mathrm{K}+$ and TEB and the rest $\mathrm{pH}$ and PBS, as well as PBS and TEA related inversely at $\mathrm{p}<0.05$. These results show sharp reduction in some proportion of chemical properties found in the flooded area, which could not be unconnected with the effect of flooded water, that likely to have resulted in the unusual increment of some chemical properties such as ECEC TEA, EC, while other like Na, Ca2+, Mg2+, TN, are reducing. This finding agreed with that made by Brady and Weil (2010) that due to presence of flood water of the period of time, some chemical properties such as AV-P, Na, and $\mathrm{Ca} 2+$ tend reduced drastically as a result of leaching effect. Likewise, study by Tian (2011) found the reduction in the level of $\mathrm{Mg} 2+, \mathrm{Ca} 2+$ and $\mathrm{Na}$ in flood affected area than control (upland) area which was attributed to the effect of leaching and dilution. Tian et al. (2017) argued that reduction found some level of chemical properties of flooded soil is more of dilution effect than leaching, due to the fact that flooding increases the solubilityof mineral nutrients. A similar argument was put forth by Kolahchi and Jalali(2013) that during a high flood, more soil nutrients dissolvein water and are lost through leaching as water infiltrates the soil.

The research assessed physical and chemical properties of forested upland and flooded soils in Yola North LGA, Adamawa State. Soil samples were collected from the upland and flooded areas in two locations within each of the Local Government Areas. These were Jambutu and Runde-Baru in Yola North LGA a.

Evaluation of the physical properties revealed that all but bulk Density showed significant difference of $\mathrm{P}<0.05$ between upland soils and flooded soils. Soil textural classes appeared similar in all locations and across depths assessment of chemical properties of the soil samples showed significant difference in OC, AV-P, Ca, K+ and TEB while the others were not significantly different at $\mathrm{P}<0.05$. Results further showed that there was high percolation rate and low capillary action of the upland areas.

From the finding of this study, it can be concluded that while some nutrient levels in both the upland and flooded forest soils of the study areas are significantly different some are not inferring that some nutrients are depleted during flooding, some are added through deposits from rivers and streams, while some are unaffected. The level of depletion and addition of such soil properties may perhaps be connected to the level and duration of flooding and the slope of the affected areas. This makes the effect of flood on forest soils and indeed any other soil unpredictable.

\section{Recommendations}

- Since flooded areas do not normally support arable farming, but support free growth to some expert, some forms of agroforestry systems could be developed by government where the upland areas are put to arable farming while the flood areas are connected to forest plantations in noting trees that show flood tolerance.

- With respect to the above recommendation further research could be geared towards identifying flood tolerant tree species for cultivation in these flood area as. This will go a living way in enhancing the forest conservation efforts of government.

\section{References}

i. Adelekan, I.O. (2011). Vulnerability assessment of an urban flood in Nigeria: Abeokuta flood 2007. Natural Hazards, 56(1), pp. 215-231.

ii. Ajibola, M. O., Izunwanne, E. M., and Ogungbemi, A. O. (2012). Assessing the effects of flooding on residential property values In Lekki Phase I, Lagos, Nigeria, International Journal of Asian Social Science, 2, 271-282.

iii. Amarawansha, E. A., Kumaragamage, D., Flaten, D., Zvomuya, F. \&Tenuta, M. (2015). Phosphorus Mobilization from Manure-Amended and Unamended Alkaline Soils to Overlying Water during Simulated Flooding. Journal of Environmental Quality. 44:2: 1252-1262.

iv. Azuhan, M. (2015). Kelantan Flood-Divine vs Anthropogenic Causes. Proceedings of National Geoscience Conference, Kota Bharu, 31 July-1 August 2015, Geological Society of Malaysia, 2-5.

v. Barton, L., McLay, C. D. A., Schipper, L. A., \& Smith, C. T. (2016). Denitrification rates in a wastewater irrigated forest soil in New Zealand. Journal of Environmental Quality 28: 20 -28.

vi. Bechtold, J.S. and Naiman, R.J. (2009). A Quantitative Model of Soil Organic Matter and Heavy Metal Accumulation during Floodplain primary succession. Ecosystems, 12, 1352-1368.

vii. Brady, N.C., and Weil, R.R. (2010). Elements of the Nature and Properties of Soils. Pearson Education, Prentice Hall, New Jersey, pp. 361-395.

viii. Cammerer, H., A.H. Thieken and J. Lammel, (2013). Adaptability and transferability of flood loss functions in residential area. National Hazards Earth System and Science, 13: 3063-3081. DOI: 10.5194/nhess-13-30632013.

ix. Chormanski, J., T. Okruszko, S. Ignar, O. Batelaan and K.T. \& Rebel, E. A. (2011). Flood mapping with remote sensing and hydrochemistry: A new method to distinguish the origin of floodwater during floods. Ecol. Eng., 37:1334-1349.

x. Churchman, G. J. \& Tate, K. R. (2016). Effect of slaughterhouse effluent and water irrigation upon aggregation in seasonally dry New Zealand soil under pasture. Australian Journal of Soil Research 24: 505-516. 
xi. Clilverd, H.M., Thompson, J.R., Heppell, C.M., Sayer, C.D., Axmacher, J.C. (2013). River-floodplain hydrology of an embanked lowland Chalk river and initial response to embankment removal. Hydrology Science Journal , 58, 627-650

xii. Connelly, A., Gabalda, V., Lawson, N., O’Hare, P. and White, l. (2015).Testing Innovative Technologies to Manage Flood Risk. Proceeding of the institution of civil engineers- water management 168(2): 66-73.

xiii. Daffi, R.E., (2013). Flood hazard assessment for river DEP catchment using remote sensing and geographic information system techniques. PhD Thesis, Ahmadu Bello University Zaria.

xiv. Dalil, M., Mohammad, N.H., Yamman, U.M., Husaini, A. \& Mohammed, S.L., (2015). An assessment of flood vulnerabilty on physical development along drainage channels in Minna, Niger State, Nigeria. African Journal of Environment Science and Technology, 9(1), pp. 38-46.

xv. Dezzeo, N., Herrera, R., Escalanta, G. and Chacòn, G. (2010). Deposition of sediments during a flooding event on seasonally flooded area of the lower OrinocoRiver and two of its black water tributaries, Venezuela. Journal of Biogeochemistry. 49:241-257

xvi. Diane, S.L., Roxane, P., Ariane, D. and Vernhar, G. (2016). Impacts of Floods on Organic Carbon Concentrations in Alluvial Soils along Hydrological Gradients Using a Digital Elevation Model (DEM). Water and Soil Resources 1(2): $208-220$

xvii. Dick, R. P. (2014). Soil enzyme activities as indicators of soil quality. In: Doran, J. W.; Coleman, D. C.; Bezdicek, D. F.; Stewart, B. A. ed. Defining soil quality for a sustainable environment. Soil Science Society of America Special Publication 35: 107-124.

xviii. Drogue, G., Pfister, L., Leviandier, T., El Idrissi, A., Iffly, J.F., Matgen, P., Humbert, J., Hoffmann, L., (2014). Simulating the Spatio-Temporal Variability of Stream Flow response to Climate Change Scenarios in a Meso Scale Basin. Journal of Hydrology 293, 255-269.

xix. Dutta, D., S. Herath and K. Musiake, (2013). A mathematical model for flood loss estimation. International Journal of Hydrological World, 277: 24-49.

xx. Ekwue, E. I. and Bartholomew, J. (2010). Electrical Conductivity of some Soils in Trinidad as Affected by Density, Water and Peat Content. Biosystems Engineering, 108(2): 95-103.

xxi. Etuonovbe, A. K. (2014). The Devastating Effect of Flooding in Nigeria. FIG Working Week 2014 Bridging the Gap between Cultures Marrakech, Morocco, 18-22 May 2014

xxii. Fan, J., Hao, M and Malhi, S.S. (2010). Accumulation of nitrate-N in the soil profile and its implications for the environment under dry land agriculture in northern China: A review. Canadian Journal of Soil Science, 90,429-440

xxiii. Food for Agricultural Organization (2014). World Reference Base For Soil Resources 2014. World Soil Resources Report 106. Rome. Pp. 978-987

xxiv. Galtima, M. and Bashir, B. A. (2002). The impact of Floods on the Riverine Communities of the Lower Benue Reaches: The Experience in Adamawa Area. Proceedings on the Expert Group Meeting on Pollution and Sediment Sources.

xxv. Gebrelibanos, T., and Assen, M. (2013). Effect of land-Use/Cover changes on Soil properties in a Dry land Watershed of Hirmi and its Adjacent Agro Ecosystem: NorthernEthiopia international Journal of Geosciences Research, 1(1), 45-57.

xxvi. Gervais-Beaulac, V., Saint-Laurent, D. \& Berthelot, J.-S. (2013). Organic carbon and Chemical Properties distribution in Alluvial Soils According to different Flood Risk Zones. Journal Soil Science Environment Management.4(2): 169-177.

xxvii. Hammond, M. J., Chen, A. S., Djordjevi' c, S., Butler, D., and Mark, O. (2015). Urban flood impact assessment: A state-of-the-art review, Urban Water Journal., 12, 14-29.

xxviii. IFRCS, (2012a). Emergency Appeal; Nigeria: Floods. 29th September, Retrieved January 10, 2018 from http://reliefweb.int/sites/reliefweb.int/files/resources/MDRNG01401.pdf

xxix. Jeb, D. N. and Aggarwal, S. P. (2010). Flood Inundation Hazard Modeling of the River Kaduna Using Remote Sensing and Geographic Information Systems, Journal of Applied Sciences Research, 4(12), 18221833

xxx. Kalshetty, B. M., Giraddi, T. P., Sheth, R. C. and Kalashetti, M. B. (2012). River Krishna Flood Effects on Soil Properties of Cultivated Area in Bagalkot District, Karnataka State," Global Journal of Science Frontier Research Chemistry, 12(6):10 - 16.

xxxi. Kefas, P.K., Zata, A.I., Philip, H.J., Ukabiala, M.E. and Ezekiel, T.N. (2016). Soil Assessment of Selected Floodplain Soil in Nigeria to Support Agriculture Advancement. International Journal of Plant \& Soil Science 11(2): 1-12,

xxxii. Kolahchi, Z. and Jalali, M. (2013). Phosphorus Movement and Retention by two Calcareous Soils. International Journal of Soil Sediment Contamination, 22, 21-38

xxxiii. Lindsell, K. M. and Prater, S. C. (2010). Abstract on "Assessing Community Impacts of National Disasters": 176178 (electronic), National Hazard Review vol. 4(4): 1 - 12.

xxxiv. Madueke, C.O., Asadu C.L. A., Eshett E.T. Akamigbo F.O.R., and Okene C.D. (2012). Characteristic and classification of soils on toposequence formed from the coastal plain sand of south-eastern Nigeria. Proceedings of the $36^{\text {th }}$ Annual Conference of Soil science Society of Nigeria.

xxxv. Medeiros, W. N., Domingos, S.M.V., Daniel, M., Francisco-de-Assis, P. and Igor, R. (2018). Apparent soil electrical conductivity in two different soil types. RevistaCiênciaAgronômica, v. 49, n. 1, p. 43-52, 
xxxvi. Njoku, C. and Okoro, G.C. (2015). Effect of Flooding on Soil Properties in Abakaliki South Eastern Nigeria. Scholarly Journal of Agricultural Science, 5(5): 165 - 168

xxxvii. Njoku, C., Igwe, T. S. and Ngene, P.N. (2011). Effect of Flooding on Soil Physico-chemical Properties in AbakalikiEbonyi State Nigeria; African Journal of Professional Research in Human Development. 7(1): 18 - 23.

xxxviii. Nkwunonwo, U.C. (2015). A Review of Flooding and Flood Risk Reduction. Global Journal of Human -Social Science, 16(2): $10-21$.

xxxix. Nurul-Akma, J., Khanan, Z., Haq, U.Y. and Bhat, I. (2015). Effects of Recent Flood on Soil Properties. Proceedings of National Geoscience Conference, Kota Bharu, 31 July-1 August 2015, Geological Society of Malaysia, 207.

xl. Nwilo, P.C., Olayinka, D.N., and Adzandeh, E.A. (2012). Flood Modeling and Vulnerability Assessment of Settlements in the Adamawa State Floodplain using GIS and Cellular Framework Approach. Global Journal of Human Social Science. 12(3), 18 - 23.

xli. O'Connor, E. J. \& John, E. (2014). The World Largest Floods: Past and Present - Their Causes and Magnitudes. International Journal of Engineering Research and Technology 3(4):12 - 21.

xlii. Obermann, M., Froebrich, J., Perrin, J.L. \&Tournoud, M.G. (2009). Impact of floods on agricultural soils in the Mediterranean. Internaltional Journal of Hydrology, 334, 99-108.

xliii. Ogbanga, M. M. (2015). Impacts of Flooding Disaster on Housing And Health In Two Communities of Ahoada East And West Local Government Area Of Rivers State. Nigerian Journal of Agriculture, Food and Environment. 11(1):44-50

xliv. Oladokun, V.O. and Proverbs, D. (2016). Flood Risk Management In Nigeria: A Review Of The Challenges And Opportunities. International Journal of Safety and Security, 6, 3: 20 - 26 485-497.

xlv. Olaore, Y. A. and Aja, G.N (2014). The Impact of Flooding on the Social Determinants of Health in Nigeria: A Case for North-South Institutional Collaboration to Address Climate Issues. Journal of Developing Country Studies, 4(22): 2 - 16

xlvi. Osakwe, S.A., Akpoveta, O.V., \&Osakwe, J.O. (2014). The Impact of Nigerian Flood Disaster on the Soil Quality of Farmlands in Oshimili South Local Government Area of Delta State Nigeria. Chemistry and Materials Research. $6(3): 24-68$.

xlvii. Osman, K. T. (2013). Flooding and Forest Soil Properties. International Journal of Forest and Soils, 10(1)7:8 - 16.

xlviii. Oviasogie, P. O. and Omoruyi, E. (2010). Levels of heavy metals and physicochemical properties of soil in a foam manufacturing industry. Journal of Chemical Society of Nigeria, 32(1): 102 - 106.

xlix. Panhwar, Q.A., Naher, U.A., Radziah, O., Shamshuddin, J., Mohd Razi, I., Dipti, S.S. and KarabaleiAghamolki, M.T. (2015). Quality and Antioxidant Activity of Rice Grown on Alluvial Flood Soil Amended with $\mathrm{Zn}$, Cu and Mo. African Journal of Botany, 98, 77-83

l. Rasmussen, C., Southard, R.J. \&Horwath, W.R. (2010). Litter type and soil minerals control temperate forest soil carbon response to climate change. Global Change Biology.1(4), 2064-2080

li. Reddy, K. R. and Patrick, W. H. (2009). Nitrogen Transformations and Loss in Flooded Soils and Sediments, CRC Critical Reviews in Environmental Control, Vol. 13, No. 4, 1984, pp. 273-309.

lii. Ruiz-Sinoga, J.D., Pariente, S., Diaz, A.R. \& Martinez, M.J.F. (2012). Variability of relationships between soil organic carbon and some soil properties in Mediterranean rangelands under different climatic conditions (South of Spain). Catena Journal, 94, 17-25.

liii. Schipper, L. A., Williamson, J. C., Kettles, H. A. \&Speir, T. W. (2015). Impact of land-applied tertiarytreated effluent on soil biochemical properties. Journal of Environmental Quality 25: 1073-1077.

liv. Shamshuddin, J., Panhwar, Q.A., Othman, R., Ismail, R., Jol, H. and Yusoff, M.A. (2016). Effects of December 2014 Great Flood on the Physico-Chemical Properties of the Soils in the Kelantan Plains, Malaysia. Journal of Water Resource and Protection, 8, 263-276

lv. Shao, M., Fu, X., Wei, X. \& Horton, R. (2010). Soil organic carbon, Ca, Mg, Fe and Total Nitrogen as affected by vegetation types in Northern Loess Plateau of China. Geoderma, 155, 31-35

lvi. Shehu, B. M., Jibril, J.M. and Samdi, A.M. (2015). Fertility Status of Selected Soils in Sudan Savanna Biome of Northern Nigeria. International Journal of Soil science 10;74-83

lvii. Speir, T. W. (2010). Soil Biochemical Properties as Indices of Performance and Sustainability of Effluent Irrigation Systems in New Zealand-A review. Journal of the Royal Society of New Zealand 32:4, 535-553

lviii. Steven, F.J and Cole, M.A. (2011). Cycles of soil: Carbon, Nitrogen, Phosphorus, Sulfur Micronutrients., Aquatic Botany, l. 88, No. 2, pp. 93 - 98.

lix. Tian, J. (2011). Study on Phosphorus Chemical Behavior and Release Mechanics in Flood Submerged Soils. Unpublished Ph.D. Thesis, Hohai University, Nanjing, China.

lx. Tian, J., Guiming, D., Raghupathy, K. \& Daren, R. H. (2017).Phosphorus Dynamics in Long-Term Flooded, Drained, and Flooded Soil. Journal of Water9 (3), 531 - 590.

lxi. Timbal, B., Power, S., Colman, R., Vivand, J., and Lirola, S., (2012). Does Soil Moisture Influence Climate Variability and Predictability Over Australia?Journal of climate, volume 1(5):1230-1238.

lxii. Ubuoh, E. A, Uka, A. and Egbe, C. (2016). Effects of Flooding On Soil Quality inAbakalikiAgroecological Zone Of South-Eastern State, Nigeria. International Journal of Environmental Chemistry and Ecotoxicology Research, 1(3): 20-32

lxiii. United State Department of Agriculture (2011) and National Institute of food and agriculture, administered by university of California, project -68002-30029. 
lxiv. United State Department of Agriculture (2011) and National Resource Conservation Service Handbook 18 Retrieved. March 12.

lxv. United State Department of Agriculture (2011). Soil survey Division Staff. 'Soil survey manual. 1993. Chapter 3, selected chemical properties. Soil conservation services. U.S.

lxvi. Wald, M. L. (2011). Nebraska Nuclear Plant's Vital Equipment Remains Dry, Officials Say' The New York Times June 27.

lxvii. Wall, D.H. (2012). Soil Ecology and Ecosystems Service. Oxford University Press, Oxford. ISBN 9780199688166

lxviii. Weil, R. R. and Brady, N.C. (2016). The Nature and Properties Of Soils. Pearson Education, Inc, Pp. 123 - 125.

lxix. Yakubu, M. and Oganuya, A.G. (2009). Pedogenesis, Weathering Status and Mineralogy of Soil on Iron Plateau (lateries), Sokoto, Nigeria. In Fana, A.O Ayodele, O.J, Salami, A.E and Ogeniyi, S.O (ed)(2009)

lxx. Yande, P. M. (2009). Impact of Floods on the Socio-Economic Livelihoods of People: A Case Study of Sikaunzwe Community in Kazungula District of Zambia. Unpublished MSC Thesis University of Free State

lxxi. Zhang, Y., Cui, B., Lan, Y., Han, Z., Wang, T., Zhang, Y., Tong, Y. (2013). Profile Distribution Characteristics of Total Nitrogen and Soil Organic Matter in Different Types of Land Use in Baiyangdian Lake. Third international Conference on Intelligent System Design and Engineering Applications. 1069-1073.

\section{Appendix}

\begin{tabular}{|c|c|c|c|c|c|}
\hline & Low & Medium & High & Unit & Source \\
\hline$\overline{\mathrm{PH}^{\mathrm{H}}}$ & $<4.0$ & $4.5-5.5$ & $>6.5$ & $\left(\mathrm{H}_{2} \mathrm{O}\right)$ & $\mathrm{e}$ \\
\hline EC & $<0.1$ & $1.0-2.5$ & $>2.5$ & mmhos $/ \mathrm{cm}$ & e \\
\hline Org C & $<10$ & $10-15$ & $>15-20$ & $\mathrm{gkg}^{-1}$ & $\mathrm{~b}$ \\
\hline Total N & $<1.5$ & $1.5-2.0$ & $>2.0$ & gkg-1 $^{-1}$ & $\mathrm{~b}$ \\
\hline Avail-P & $<8.0$ & $8-20$ & $>20$ & $\mathrm{mgkg}^{-1}$ & $\mathrm{~b}$ \\
\hline Exch. Ca & $<5.0$ & $5-10$ & $>10$ & $\mathrm{Cmol} / \mathrm{kg}$ & c \\
\hline Exch. Mg & $<1.0$ & $1-3$ & $>3.0$ & $\mathrm{Cmol} / \mathrm{kg}$ & c \\
\hline Exch. Na & $<01.6$ & $0.16-0.50$ & $>0.50$ & $\mathrm{Cmol} / \mathrm{kg}$ & c \\
\hline Exch. K & $<0.3$ & $0.3-0.6$ & $>0.6$ & $\mathrm{Cmol} / \mathrm{kg}$ & c \\
\hline ECEC & $<12.0$ & $12-25$ & $>25$ & $\mathrm{Cmol} / \mathrm{kg}$ & d \\
\hline $\mathrm{BD}$ & $<1.3$ & $1.3-1.6$ & $>1.6-1.9 \mathrm{gcm}^{-3}$ & & $\mathrm{a}$ \\
\hline
\end{tabular}

Table 7: Rating of Soil Interpretation

Source: A. Harte (Per.Com), B. AduayiEt Al. (2005), C. Usman, B.H (2005).

D.Http://Www.Environment.Nsw.Gov.Au/P4.E.Hart Et Al., 1997 